HABIB BORJIAN

(CAUCASIAN CENTRE FOR IRANIAN STUDIES, YEREVAN)

\title{
TWO MAZANDARANI TEXTS FROM THE NINETEENTH CENTURY*
}

\section{RÉSUMÉ}

L'article donne la transcription, la traduction et le glossaire pour deux textes écrits en 1889 à Bārforush, dans le Māzanderān, et publiés en facsimilé par Jacques de Morgan. La langue des textes, le mazanderani ou le tabari moderne, est pour l'essentiel similaire à celle parlée aujourd'hui par plus de trois millions de locuteurs dans la province iranienne du Māzanderān (au sud de la Caspienne). On note cependant plusieurs mots aujourd'hui disparus, ainsi que certains traits grammaticaux identifiables uniquement grâce à l'existence d'autres documents en mazanderani de la même période. La présentation de ces textes contribue ainsi à l'étude de la langue du Māzanderān, une langue iranienne nordoccidentale, aujourd'hui encore assez méconnue. Documents historiques, les textes donnent plus de détails que les autres sources sur certains événements. Les textes sont suivis des remarques historiques circonstanciées.

Mots clés : le tabari moderne ; le mazanderani ; dialectes caspiens ; langues iraniennes ; analyse textuelle ; manuscrits du XIX ${ }^{\mathrm{e}} \mathrm{s}$. ; antisemitisme ; histoire iranienne.

\section{SUMMARY}

This article transcribes, translates, and compiles a glossary for two Mazandarani texts written in 1889 in the town of Barforush and published as facsimiles by Jacques de Morgan. The language of the texts, Mazandarani or New Tabari, is fundamentally similar to that spoken today by more than three million people in the Persian province of Mazandaran, located south of the Caspian Sea. However, there are several extinct words and grammatical traits in the texts, which could be identified only by drawing on other surviving Mazandarani documents of the same period. The texts are meant to contribute to the study of the largely understudied language of Mazandaran, a northwestern Iranian language. They may also serve as historical documents, for they relate certain events in such details not found in other sources. Ample historical remarks follow the texts.

Keywords: New Tabari; Mazandarani language; Caspian dialects; Iranian languages; textual analysis; nineteenth century manuscripts; anti-Semitism; Persian history.

* I am indebted to my wife Maryam for her assistance in transcribing and translating the Mazandarani texts. I also want to thank Mr. Fakhr-al-Din Surtiji and Dr. Javād Neyestāni for their valuable comments on the historical context as well as on certain words. My thanks go also to Ms. Dorothy Staub for her careful editing and to Dr. Douglas Val Ziegler for checking the Mazandarani texts against their translation and making significant comments. 
During the nineteenth century several European scholars, travelers, and diplomats collected ethnographic and linguistic data from the Caspian provinces of Māzandarān and Gilān in northern Persia. Among their works stands out Jacques de Morgan's five-volume Mission scientifique en Perse, with a wealth of information on the southern shores of the Caspian sea. Its fifth volume, dedicated to linguistics, covers several languages spoken in Persia, including Caspian dialects, for which a list of 877 glosses is tabulated for nine localities (Rehna, Bārforush, Semnān, Āmol, Kelārsak, Tonekābon, Kojur, Rasht, and Menāra-bāzār). This glossary is followed by the facsimiles of two Mazandarani manuscripts which have neither been translated nor commented upon since their publication. The first text is a local account of the town of Āmol, the old provincial capital of Mazandaran, relating its glorious past and its monuments. The second text provides valuable information on Bārforush (now Bābol), the largest and chief commercial town of Mazandaran at the time of the composition of the text. This latter text depicts the establishment of the town's historical monuments and holy shrines as well as two contemporary events, including a vivid account of a pogrom which occurred in the Jewish quarter of the town, and its consequences.

Apart from their contents, the texts are of considerable dialectological interest regarding the Mazandarani language, which remains greatly understudied in spite of its large number of speakers and long literary tradition that rivals that of New Persian in age. The language's peak can be found in the early Islamic centuries, when it thrived under the long reign of the independent and semi-independent provincial rulers of Tabaristān, commonly known as Ispahbads. Various eleventh- and twelfth-century works written in Tabari (the older form of Mazandarani), such as Bāvand-nāma, Nèki-numa, Šakara, and, perhaps, Marzbān-nāma are lost in the original language; only a number of poems and individual verses are but poorly preserved by means of Persian works connected to the province. From the post-Ispahbad era survives the word-by-word Tabari translations added interlineally to several manuscripts. ${ }^{1}$ After several centuries of silence, a new series of Mazandarani documents emerges in the nineteenth century, thanks to the efforts of European travelers and diplomats who aimed at documenting the language. Their resulting works are considerable; from among them stands out Kanz al-asrär, several collections of verses attributed to the legendary Mazandarani poet Amir Pāzvāri, ${ }^{2}$ compiled by

For an overview of the sources and studies on Old Tabari, see Borjian 2004a.

See Borjian and Borjian. 
Boris Andreevich Dorn. Several other collections of popular poems and songs, as well as individual sentences and words, were published by Aleksander Borejko Chodźko (1842), Il'ya Nikolaevich Berezin (1853), and G. V. Melgunov (1868a). ${ }^{3}$ Also from the mid-nineteenth century has survived a versified Mazandarani-Persian dictionary, which was edited by Sādeq Kiā (1947). ${ }^{4}$ Moreover, there are a few works of prose, the most valuable of which are the texts of the present study, and an account of the Babi-state conflict at Shaikh Tabarsi published by Dorn (1865). ${ }^{5}$ These prose texts are essential to the study of the language as it was spoken in the nineteenth century.

De Morgan provides no explanation on the texts he collected other than they both are written in the dialect of Bārforush. Each text, however, has a colophon in Persian stating that it was written in 1889 as requested by de Morgan, who was lodging at the residence of Mirzā Yusof Khān, agent-e qonsul-e Rus, i.e. the resident commercial consul of Russia (Texts I.51-56, II.125-135). The scribe introduces himself as Hajji Āqā, the secretary of the consul. The first text (pp. 248-251) is in nasta'liq pen and the second (pp. 252-260) in naskh, and both are vocalized by diacritic symbols. The manuscripts are composed of 13 to 16 lines per page, without any organization or punctuation.

Following are a transcription and translation of each text. The transcription recasts the texts in numbered paragraphs. The vertical bars signify the end of lines in the original script, and the numbers in raised parentheses refer to line numbers assigned on the facsimile of each text. The translation is meant to remain as close as possible to Mazandarani words and grammar. As the composition of the texts is not always selfexplanatory, certain material is added in square brackets for clarification, while explanations are given in parentheses. The texts are followed by historical and linguistic commentaries and a glossary.

\section{TEXTS (TRANSCRIPTION AND TRANSLATION)}

\section{I.1. Text I}

1. (1) $\bar{A} m ə l^{-\mathrm{e}}$ avvəl|Aspe-kəlā [ə]. Gspe-kəlāe ${ }^{-\mathrm{e}}$ var Sabzə Məydun Mir Bəzərg bənā-e I qadim hassə. gənənə bənā-ye Šāh Abbās hassə.xub jā-yi hassə. təmām̌̀ I ājər-e kāši dərəst hākərdə. xəd-e Mir Bəzərg ${ }^{-e}$

See Borjian 2006a ; id. 2006c.

See Borjian 2008.

See Borjian 2006b. Other Mazandarani prose works are those translated from Persian literature in Kanz al-asrär I, pp. 1-1 22; and the Mazandarani translation of a passage from Tufān al-bokā, in Berezin, II, pp. $72-79$ (studied in Borjian 2005a). 
var hūz dārnə I xale gat hassə. Sabzə Məydān-e var əttā qal'ə dārnə gənənə "Xandəq".. ${ }^{(5)}$ az qərār-i ke gənənə māl-e Jemšid-e Jam biə.

2. yək pəl dārnə Âməl, dəvāzdah I pəllə dārnə. bənā-ye qadim hassə. yək nafər hāji daiə Mašāi biə.l in dəvāzdah pəllə-rə dah daf'ə dərəst hākərdə, ū bavərdə. un-vaqt I badiə pišraft nārnə, bā ešq-e dəvāzdah emām dərəst I hākərdə; on-vaqt ū navərdə.

3. pəl bə-on-var, qadim ke Āməl-rə $\left.\right|^{(10)} \overline{\mathrm{u}}$ bavərdə, al'ān zamin hassə. mardəm binj kənnənə. Grāqi un I melk- ${ }^{\mathrm{r}}$ ə xarinnənə, vərə kannənə, $\overline{\mathrm{u}}$ vannənə, təlā, noqrə, mərvārid, l ba'zi asbāb-e digər girnənə. vaqt-ē un zamin-rə I kannənə, xānə, hammām, masjəd, sardābə xāk ${ }^{-\mathrm{e}}[\mathrm{ja}]$ dareno.l

4. Āməl Pā'in Gonbod dārnə. kār-e gonbod az ājər hassə. sə-tā $\left.\right|^{(15)}$ gonbod dārnə. əttā gat hassə, do-tā kučək hassə. gonbod-e I dūr-ə-var har-jā-rə kannənə ājər dar-enə - ājər dərəst dar-enə.I

5. əttā masjəd dārnə az qadim hassə, Masjəd-e Emām Hasan mašhur I hassə. Āməl-rə sə daf'ə ù bavərdb, in masjəd-rə ū navərdə.l al'ān ke xəšt-kan zamin-rə kanm - xəšt bairən - xale ${ }^{(20)}$ kannə, ma'lum hassə sə daf'ə Āməl-rə ū bavərcb.

6. Āməl I gatə šahr biə.əttā sar-e Āməl Salhār biə. taraf-e I qeblə, jonube Āməl, Āləšə-rū biə. šəmāl-e Āməl Čăl-ə-lpəl biə. pā'in-e Āməl čahāršanbe-bāzār dārnə.l qadim Āməl xale gat biə, čahāršanbe ruz unjə l ${ }^{(25)}$ bāzār kərdənə. in-e vər, vərə gənənə "Čahāršanbe Bāzār".।

7. čahār tan emāmzādə Āməl kat ə; əttā Emāmzādə Ebrāhim,l əttā Sayyəd Sə-tan, əttā Bibi Roqiyə, attā Emāmzādə Ali I gənənə yā [?]. Emāmzādə Ebrāhim az ājər hassə, vəne sar-ruzə-e I dələ[- rə] garj ${ }^{-\mathrm{e}}$ həmrāh əspe hākərdənə. əttā āb-ənbār dārnə I ${ }^{(30)}$ Mir Bəzərg-e var. hamān vaqt ke Mir Bəzərg-rə dərəst I kərdənə, vərə dərəst hākərdənə. bəhārəmāh vəne ū xale sard hassə.I təmām-e Āməl hamin ū-rə xərnənว.

8. Mir Bəzərg-e dələ *maqbarə-e bālā I təmām bā xatt-e kāši banəvešt ə. darun-e Mir Bəzərg vəne dūr I bā kāši xat naqš banəvešt ə; xatt-e

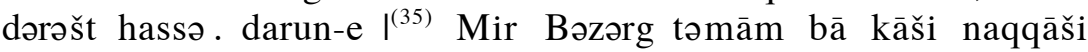
hākərdənə; ba'zi bar-ham I baxərdə - ba'zi dārnə. do-tā masjəd gat dārnə, do pahlu sahn I bālā hojrə dārnə - ba'zi xərāb ba'zi dārnə.

9. in Āməl-rə I əttā kijā ābād hākərdb, vəne esm-rə gənənə " "Āmelə”. in I

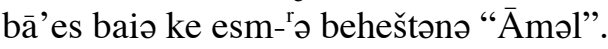

10. har kəjə-rə kannənə I ${ }^{(40)}$ ājər dar-enə - ba'zi masjəd, ba'zi hammām, ba'zi xānə, ba'zi sardābə.l aksar-e jā āb-ənbār dar-enə. aksar-e jā

6 The word may also read as gət-ənə 'they used to say'. 
qabər dar-enə.l asbāb darə qab ${ }^{\circledR}$ r-e dələ, šamšir, kārd; māl-e zonhā I dastband-e təlā noqrə dar-enə. har kas Āməl-rə jā dərəst kənnə - I zamin kannənə - xəšt dar-enə, jā dərəst kənnənə.

11. əttā ${ }^{45)}$ Bāqəšāh dārnə Āməl. az qadim ve Bāqəšāh biə.l nārənj, mərrəkbāt, ${ }^{7}$ hamə-jur- ${ }^{\mathrm{r} \partial}$ dāštə. əttā sāl I sərmā hākərdə; dār hamə-rə xəšk hākərdə.l al'ān mardəm vərə "bāq" gənənə. ${ }^{8}$

12. avvəl-e Āməl I məsallā dārnə. qadəmgāh-e Xezr hassə. [vərə] "Gonbod-I ${ }^{(50)}$ dār" gənənə. hamə čahāršanbe šū Xezr enə. nəmāz । xunnənə. in naqš-e gonbod-e Āməl hassə.

\section{Translation}

[Āmol]

1. The beginning of Āmol [is] Aspekalā, by which lays Sabza Maidan. [There] stands the old structure of Mir Bozorg's [shrine]. They say: it is a building from [the time of] Shāh 'Abbās, it is a fine place. He made it all from bricks and tiles. ${ }^{9}$ Right alongside Mir Bozorg lies a pool that is very big. Near Sabza Maidan there is a castle called Khandaq ('moat') which belonged to Jamshid the Yima.

2. Āmol has a bridge with twelve arches. It is an old structure. There was a hăjjji, from the Mashā'i [clan], who rebuilt these arches ten times, [but every time they were] destroyed by flood. When his efforts proved unsuccessful, he [finally] reconstructed [the bridge] for the love of the twelve [Shi'i] Imams - thus it survived torrents.

3. Beyond the bridge, where old Āmol was located [before] it was inundated, there is now [farm] lands, [where] people grow rice. [Once Persian] Iraqis buy that estate, plow and irrigate it, [and luckily] obtain gold, silver, pearls, and certain other items. When digging the land, there come out of the ground dwellings, bathhouses, mosques and burial chambers.

4. Āmol has Pāyin Gonbad (lit. 'Lower Dome'). The dome is made from bricks; it has three domes - one is big and two are small. Round about the Dome, wherever they dig, there comes out brick - whole bricks come into view.

5. There is a mosque from the old times, known as the mosque of Imam Hasan. Āmol has been devastated by flood three times - and this mosque has survived [all disasters]. Now, when a digger excavates the

Sic! Cf. Pers. morakkabāt.

The word reads also kannənə 'they dig'. In the text: "brick tile". 
earth to obtain mud bricks, once he digs deep down, it becomes clear that Âmol has been flooded three times.

6. Āmol used to be a big town. One end of it was Salhār. In the direction of Mecca, to the south of Āmol, was the Ālashā River. To the north was Chālapal. Below (i.e. north of) Āmol there used to be a Wednesday market. In olden times, [when] Āmol was big, a market was held there on Wednesdays; thus the name "Wednesday Market".

7. There exist four shrines in Āmol: the shrines of Ebrāhim, Sayyed Setan, Bibi Roqiya, and the shrine of 'Ali. [...?] The shrine of Ebrāhim is made from bricks; the interior of its dome is whitened with plaster. ${ }^{10}$ It has a [endowed?] cistern towards the [shrine] of Mir Bozorg. It was built together with the latter. In the spring its water is very cold and is consumed all over Āmol.

8. Inside Mir Bozorg, above the shrine, it is covered with inscriptions on tiles. Inside the building there is work of tile calligraphy all around. Indoors, there are tile murals, partly lost, partly [still] there. It has two large mosques; on two sides there are upper chambers, parts of which are still standing.

9. Âmol was founded by a girl named Âmela; that is why it was named Âmol.

10. Anywhere they dig, there emerge bricks - from the [buried] mosques, bathhouses, dwellings, and burial chambers. At most sites come into view cisterns and there are tombs. In the graves there are implements [like] swords [and] daggers; and female items [like] gold and silver bracelets turn up. Whoever builds a house in Âmol, they dig up the ground, out come mud bricks [with which] the house is built.

11. There is a royal garden in Âmol; from olden times, it was a royal garden. It used to have every kind of orange and citrus [trees]. One year it turned so cold that all trees withered. Now the people call it a garden.

12. At the outer edge of Āmol there is a Mosallă. It is [founded on?] the footprints of Khidir (i.e. Elias). They call it "Gonbod-dār" ('having a dome' or 'dome-tree'). Every Wednesday night Khidir comes and they read communal prayers. This is the sketch of Āmol's dome (or: this is sketched on the Âmol's dome).

10 Alternative reading: Emāmzādə Ebrāhim az ājor hassə, vəne sar-ruð ə; dələ garj ${ }^{-e}$ həmrāh əspe hākərdənə 'The shrine of Ebrāhim is made from bricks; it has a dome, the interior is whitened with plaster.' 
Facsimile Text I (after: de Morgan, 1894-1904, vol. V pp. 248-251).

LÉGENDES SUR LA VILLE D'AMOL.

(En marandénini de Barfiourh.)

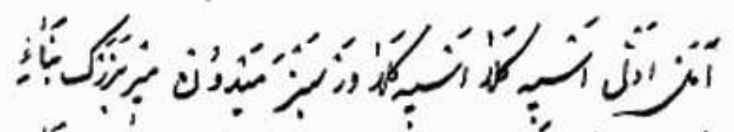

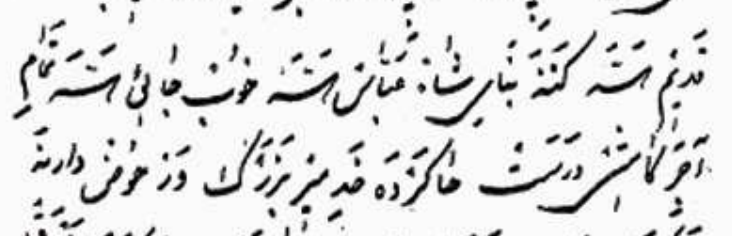

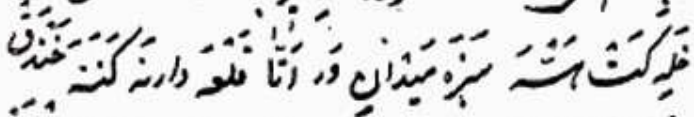

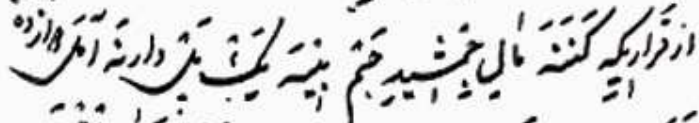

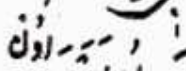

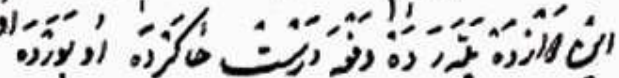

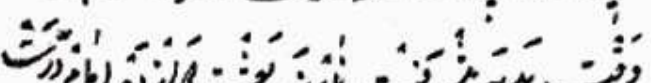
(الرذه

㭗

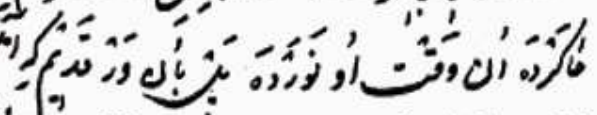

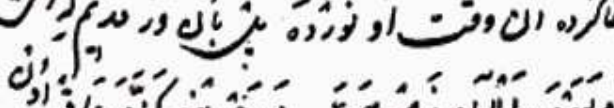

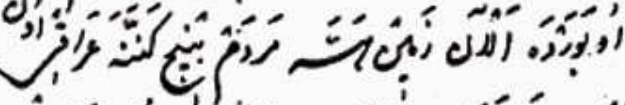

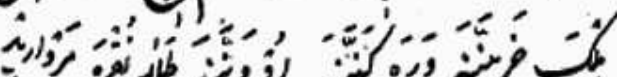

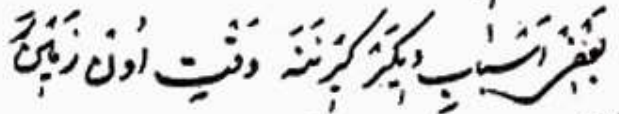

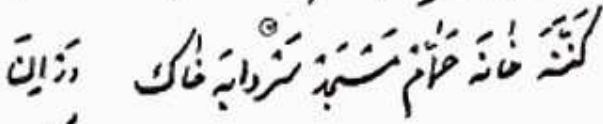
'́n' 
Text I, continued (2).

LANGUES ET DIALBCTES DE NORD DE LA PERSE. 249

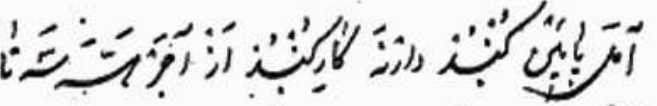

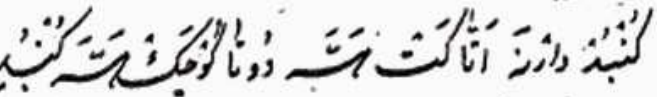

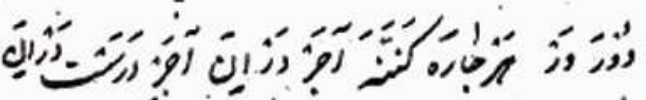

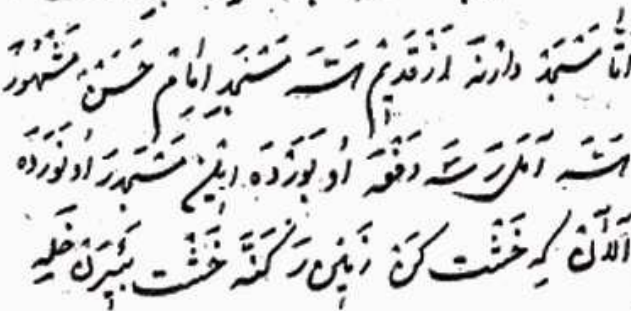

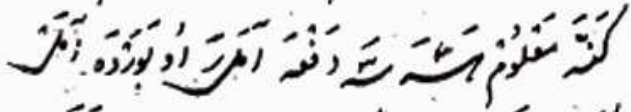

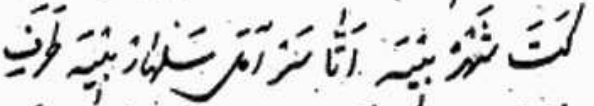

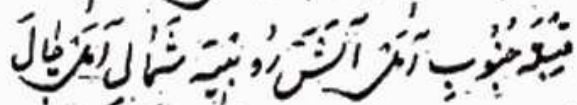

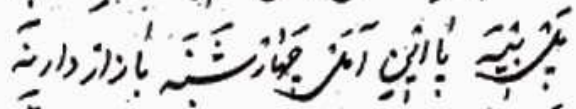

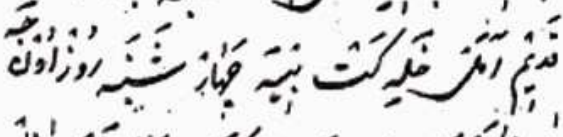

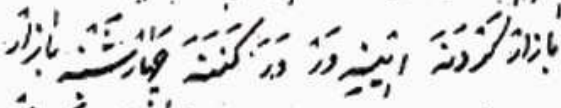

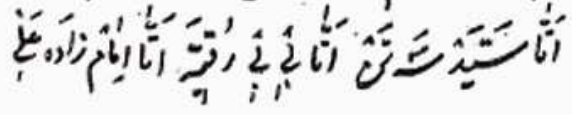


Text I, continued (3).

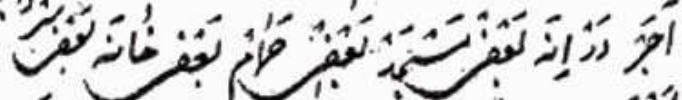

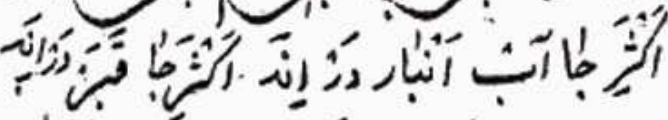

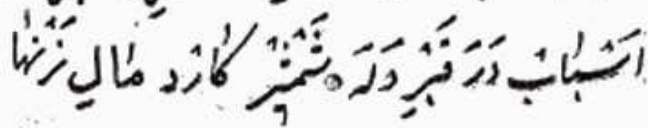

$$
\begin{aligned}
& \text { - }
\end{aligned}
$$


Text I, cont. and end (4)

LANGUES ET DIALECTES DU NORD DE LA PERSE.
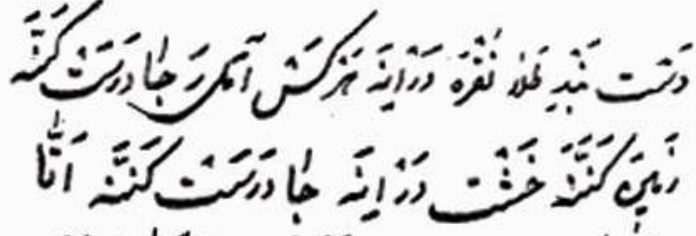

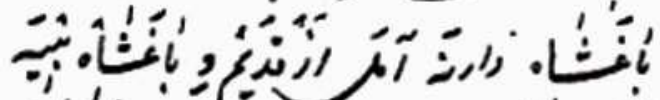

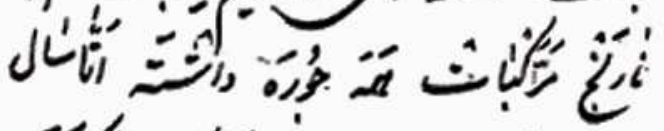

(45)

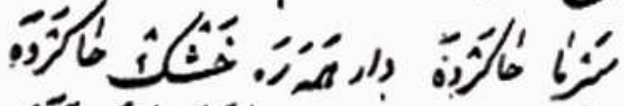

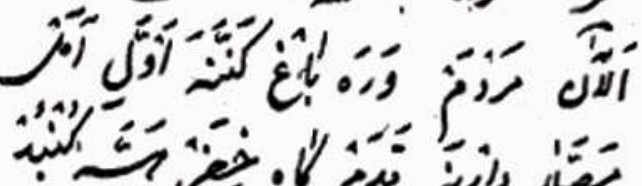

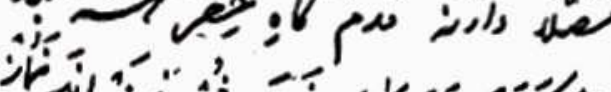

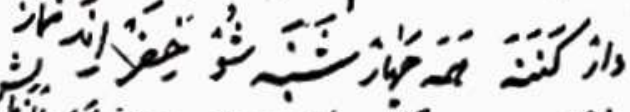

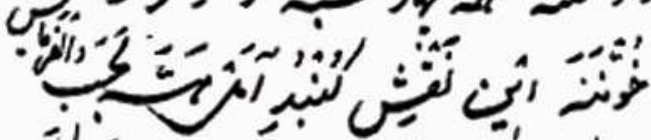

(50)

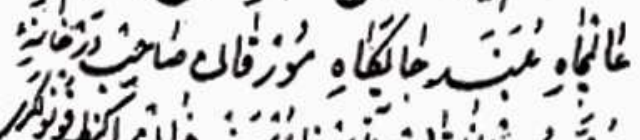

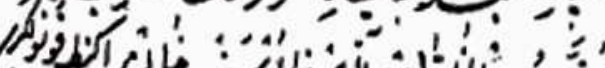

"

Ut"

-

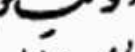

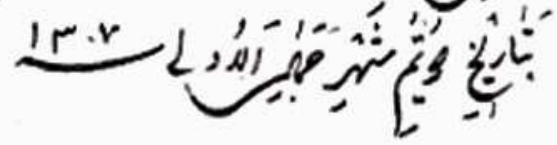




\section{I.2. Text II}

\section{Hekāyat-e sābeqa-ye Bārforuš}

1. Bārforuš avvəl mašhur biə bə Bārforuš Deh - ke hamə jā jangəl biə.l Āstunə o ${ }^{11}$ Šohadā-bən āb-annān biə. asl-e šahr-e qadim I Āməl o Sāri biว.

2. xud-e Âstunə laləjār biə, ū dāštə.I dar miān-e ù əttā jā tappo biə. mardəm ke iamunə o šinə, $\left.\right|^{(5)}$ badinə ke əttā-xale kəlāj sar-e on tappə jam' ənə, qār-qār I kərdənə. mardəm hamə še xəd bə xəd gətənə, “čəči-e vāsse I in-jə kəlāj jam haiə?" tā-in-ke əttā mardi-rə xū-nəmā baiə ke I in-jə āstunə hassə. mardəm ke bašnussənə, biamunə in-ljə-ґə qabr bəsātənə. kam-kam mardəm in dūr-ə-var biamunə $\mathrm{I}^{(10)}$ jam bainə xənə bəsātənə. on-vaqt šāh ke badiə I mardəm jam bainə xənə bəsātənə o in-jə-rə qabr dərəst I hakərdənə, šāh ham in qabr-e sar-rə gonbod bəsātə,I vəne num-rə beheštənə Kəlāj-ə-Mašhad. in qabr ə bārəgāh- ${ }^{\mathrm{r}}$ । I dar həzār ə dah sāl-e piš dərəst hakərdənə.I

3. ${ }^{(15)}$ avvəl Bābəl hamin šahr-e dələ biə. mardəm ke kam-kam I xənə jam bainə bəsātənə, ${ }^{12}$ Bābəl-rə bavərdən’ birun-e šahr I qərār hədānə.

4. on-vaqt in-jə Bāqəšāh nadāštə.I dar ahd-e Šāh Abbās hokəm baiə Sabzə Məydān-e var- ${ }^{\mathrm{r}} \partial$ I əttā amārət bøsātənə. amārət-e dūr-ə-var-rə bakanninə, ${ }^{(20)}$ Bābəl-e ù biārdənə ${ }^{13}$ amārət-e dūr-ə-var-rə ù davəssənə.l vəne num-rə beheštənə Dəzzək-ə-čāl. avvələ ke hanuz ū I navəssənə, Dəzzəkəčāāl-e dələ-ı əttā amārət-e digər bəsātənə.l hefdah tā mil-mil dərəst hakərdənə; vəne bālā-rə I əttā dast amārət bøsātənə. amārət ke təmun I ${ }^{(25)}$ baiə, on-vaqt vəne dūr-ə-var-rə ù davəssəna. har I vaqt ke xāssənə burən on amārət-e dələ - nū I dāštənə *dāyəm ū-e dələ daiə - nū-rə səvār bainə I šinə on amārət. al'ān on amārət hamo I xərāb baiə hamun hefdah tā mil bamunəssə.

5. Sabzə-| ${ }^{(30)}$ Meydun-e var šast-həftād sāl-e piš əttā I qand-ə-paj-xənə bəsātənə. jami'-e asbāb-e qand-paji-rə az Orusiyə I biārdənə. moddat-i dar Bālforuš qand bapətənə barutənə. vəne I sahāb ke bamərdə, hamə asbāb-e qandpaji-rə mardəm bavərdənə.I vəne xəšt ə čū-rə ham bavərdənə. al'ān ham ba'zi on asbāb $\left.\right|^{(35)}$ hanuz kat ə; ke divon əsā zabt hakərdə,

6. Dəz əz -čāl-e ū-e dələ har I sāl-e zəməstun hamə-jurə mərq ništ biə. mardəm hamə I šinə əškār kərdənə, vardənə xərdənə. on sāl I ke šāh biamuə Bārforuš, qarəq hakərdə ke mardəm tir I xāli nakənən; har kasi tir xāli hakərdə vəne dast-e təfang-rə $\mathrm{I}^{(40)}$ bairən. mardəm az tars digər

11 Stands for the script form $v a$ 'and' throughout the text.

12 The proper word order would be: jam bainə xənə bəsātənə.

13 For the written form $<b^{a}-y-\bar{a}-r-d^{a}-n^{a}>$. 
təfəng nušānə.l əsā ham hamu-ti qarəq hassə, ammā xalvət əttā-əttā tir I xāli kənnənə.

7. hamān vaqt ke Bāqəšāh-rə dərəst I kərdənə, rāstə-e bāzār-e dələ ruxənə bəsātənə;। ajər-e jā farš hakərdənə. hamə sālə ke zəməstun ${ }^{(45)}$ biə, Bābəl-e jā ū sar dānə, də māh dərəst I tu-ye bāzār ū kašiə šiə, mardəme čəlū sard I biə. tāvəstun on čəlūhā-ye ū xale sard biə. əsā I on bāzār rū bar-ham baxərdə, Šahrū dərəst hakərdənə.l əsā hamə sālə Šahrū-rə ū vannənə, mardəm-e čəlūhā hamə $\left.\right|^{(50)}$ dar zəməstun ū šunə. tābəstān mardəm hamə on čəlūhā-e I ū-rə xərmənə. xale sard hassə.

8. Bālfəruš nazdiki-e Āqərū I əttā məsallā ham dārnə. har-vaqt vārəš nakərdə,I pišnəmāz šunə on məsallā; ${ }^{14}$ attā-xale mardəm vəne həmrāh I šunənə, on-jə nəmāz xunmənə - vārəš kənnə.

9. Bālforuš $\left.\right|^{(55)}$ əttā masjəd dārnə ke māl-e qadim hastə. vəne númə ${ }^{15}$-rə gənənə I Maqbəre. on-jə *xāssənə on masjəd-rə bəsāzənd. ${ }^{16}$ də-sə I daf'ə bəsātənə, vəne qeblə kaj baiə. xāssənə ke I qeblə-rə rāst darbiārənd, ${ }^{17}$ natunəssənə. āxər-sar I beheštənə. sə-čahār ruz ke begzeštə, badinə vəne $\mathrm{I}^{(60)}$ dəvāzdah tā pāyəhā hamə bəsāt ə; vəne qebb ham əti I rāst hastə ke mi sar nazənnə. hamə gənənə ke in I dəvāzdah pāyə-rə dəvāzdah emām kār beh ${ }^{e}$ štə bəsātə ke I qeblə rāst dar-biamuø.

10. Bālforuš əttā Yahudi mahallə I dārnə; həftād-həštād xānə bunə. dar bist sāl-e $I^{(65)} *$ piš əttā Grāqi mardi ${ }^{\text {e }}$ qarib biə; biamu Bārforuš I manzəl hakərdə. əttā kijā dāštə. faqir binə. əttā tikkə I kəlā-pišə yərāq əttā Yahudi-e jā baxriə še kijā-e I vāsse. še manzəl ke bavərdə, yərāqrə vəne kijā badiə I zāye' hassə. kijā [o] vəne per har də-tā bavərdənə Yahudi $\left.\right|^{(70)}$ mahallə. on mardi-rə xiāl biə ke Yahudihā-ye søre yək-sar I navenə dələ burdən. še darəsar-e Yahudi hərəssāå, I še kijā-rə səre ${ }^{-\mathrm{e}}$ dələ rāi hakərdə.

11. bə-qadr-e nim sāat I darəsar hərəssāa, badiə vəne kijā birun nilamu ${ }^{\curvearrowright}$; səre $^{-\mathrm{e}}$ darun vəne kijā-e nārə-nārə enə. ${ }^{(75)}$ yək-daf'ə on Yahudi-e səre ${ }^{-\mathrm{e}}$ dələ burdə. badiə I Yahudihā vəne kijā-rə lu zannənə, davəndi-e I kijārə zannənə, kijā darə mirnə. kijā-rə duš haitə on səre ${ }^{-\mathrm{e}}$ jā I birun biārdə bavərdə še manzəl. vəne manzəl I ham masjəd-e Kāzem-beyk biə. tā

14 Note incompatibility of tenses: nakardə 'did not, would not' vs. ̌̌u-nə 'he goes, he will go'.

15 Formally num 'name'. The appenthesis -ə is added arbitrarily and has no morphological value; e.g. ketābs' ${ }^{r}$ ' häde or ketābə-ro hāde 'give the book?

16 bəsāz-ənd 'that they build'; the final $d$ is superfluous for the 3rd person plural subjunctive ending in Mazandarani.

17 biär-ənd for the Mazandarani biär-ən 'that they bring'. Again, the final $d$ is added under Persian influence. 
manzəl bavərdə kijā-e ${ }^{(80)}$ vəni $^{-\mathrm{e}}$ var o vəne dohun ${ }^{-\mathrm{e}}$ var xun em. hantā bənə I kijā-rə beheštə, kijā bamərdə.

12. mardəm on šū jam'iyət hakərdənə.I badinə Yahudihā kijā-rə bēxud bakuštənə. fardā səvāhi I hamº-e Bālfəruši jam hainə, yək-sar dakəlessənə Yahudi [mahallə-e] I dələ. az səvāhi tā nahār-e vaqt čahārdah nafər zən ə ${ }^{\left({ }^{(8)}\right)}$ mard-e Yahudi-rə bakuštənə; har-či dāštənənadāštənə, hamə-rə tārāj hakərdənə. vəšune I səre-xənə-rə taš hədānə. Dāniāl Yahudi-rə I hamun vəne səre dələ ${ }^{18}$ vəne ləhāf-rə naft bazunə, I Dāniāl-rə vəne dələ dapitənə, taš hədānə. harči vərə I ${ }^{(90)}$ gətənə, "te pil kəjə darə?" gətə, "me kəng-e dələ darə". āxər I bəruz nədāə.

13. Yahudihā əti batərsinə; hamə fərār hakərdənə I burdənə mardəm-e səre-xənə dakəlessənə, az tars gətənə, "əmā Məsəlmān baimi!" bə qadr-e haft-hašt māh Məsəlmun I bainə. ${ }^{19}$ Məsəlmunhā ham vəšun-rə va'də git’nə. ${ }^{(95)}$ tā-in-ke šāh hokm hakərdə ke har kas māl o pil-e I Yahudihā-rə bavərdənə, pas hadeən. az divon I ma'mur biamu?. avvəl sarešmār ${ }^{20}$ hakərdənə; sar-ē ${ }^{21}$ dah təmən,I bist təmən, tā sad təmən hai[tə]nə. gətənə, tā I čehel həzār təmən sarešmārân haitənə.

14. Yahudihā $I^{(100)}$ badinə ke vəšun-rə komək hakərdənə, inhā I ke Məsəlmun bainə, ${ }^{23}$ ay biamunə burdənə Yahudi I bainə. əsā, Yahudihā səre-xən ${ }^{2}$-e xub-i az ājər I bəsātənə; hamə-ø gač-e jā əspe-kāri hakərdənə.l al'ān hamə təjārət kənnənə.

15. piš az Yahudi əttā mardi daiə I $^{(105)}$ vəne num-rə gətənə Qāsəm Aliābādi. ve luti $0^{24}$ kallə-šaq I biə. [əttə] Mirzā Masih daiə, vazir-e Māzəndərun biə. Qāsəm I Aliābādi vəne nūkər biə.mardəm hamə vəne jā tarsinə.l šū šiə, mardəm-e darəsar dar zuə, gətə, "fəlun qadər pil I hade! mən xāmmə". mardəm az tars vərə pil dānə; vəne esm I ${ }^{(110)}$ bəruz nadānə. mardəm az dast-e ve tang biamunə.

16. tā-in-ke I Šāzdə-e Yaminoddowlə Bāləfəruš biamu Qahhārqoli Xān-e I ətāq manzəl hakərdə. əttā šū in Qāsəm Aliābādi I arəq baxərdə biə,25

Spelled $\left\langle\mathrm{d}^{\mathrm{a}}-\mathrm{l}^{\mathrm{e}}\right\rangle$.

bains 'they became'. The expected form is bins 'they were'.

Written $\left\langle\mathrm{s}^{\mathrm{a}}-\mathrm{r}^{\mathrm{e}}-\mathrm{s}^{\mathrm{a}}-\mathrm{m}-\overline{\mathrm{a}}-\mathrm{r}\right\rangle$, it was adjusted regarding another occurrence two lines down. Alternative reading: sare šmmār 'house counting'.

$s a r-\bar{e}$ 'each head/person'. It may also be read as sare-e 'each house'.

Here sarešmār seems to be used as an adverb, meaning 'via census'.

Should read bai bins 'they had become'; note that no periphrastic form is found in the texts.

24 Written luti-e va.

25 Spelled $<\mathrm{b}-\mathrm{y}-\mathrm{y} \mathrm{y}-\mathrm{h}>$. 
xātun ${ }^{26-e}$ var [jā] dāštə šiə vazir-e I səre. əttā səyyəd-e Lāləvāi dāšt šiə še manzəl.|(115) Qāsem Aliābādi Gfrādārebən əttā sang- ${ }^{\mathrm{r}}$ ə baitə I bazuə Səyyəd-e sar-rə. Səyyəd bamərdə.

17. Šāzdə hokm hakərdə I bə vazir, ke hokman Qāsəm Aliābādi-rə xāmmə. həzār ma'rəkə-šivə | bazunə, Qāsəm- ${ }^{\mathrm{r}} \partial$ baitənə biārdənə Šāzdə-rə hədānə.l

18. Šāzdə xāssə bakuše; Qāsəm-e mansubun biamum; čahārsad təmən dānə ${ }^{(120)}$ šāzdə-rə ke Qāsəm Alīāādi-rə nakuše. qabul nakərdə vərə,l on fardā səvāhi hokm hakərdə mirqazəb vərə bakuštə.l farrāšhā Qāsəm- ${ }^{\mathrm{r}}$ ə luš bakəšim bavərdənə Šohadā-bən I čəlū-e piš dapətuninə. sə ruz Yahudihā kašik I bakəšinə. ba'd az sə ruz vəne mansubun baitənə $\left.\right|^{(125)}$ dafn hakərdənə.

\section{Translation}

An account of the history of Bārforush

1. Bārforush, originally known as Bārforush village, was all [surrounded by] woods. [The quarters of] Āstāna and the Shohadā-ban used to be a water reservoir. [In Mazandaran, only] Āmol and Sāri were old towns.

2. Āstāna used to be simply a marshland with water; in the middle stood a hill. People who went back and forth would see (lit. 'saw') a lot of crows assemble on top of the hill, crowing. People would ask themselves, why the crows gathered round here. Eventually a man had a dream that this place was a shrine. Upon hearing this, people came here and built a tomb. Gradually people gathered in the area and built houses. Then, when the king realized that people gathered and built houses and erected a tomb, he constructed a dome on the mausoleum, which was named the Kalāj Mashhad ('tomb of crows'). This splendid mausoleum was built 1,010 years ago.

3. Originally the Bābol [river] would flow through the present town. When the people gradually gathered and built houses, the Bābol [river] was diverted around the town.

4. At that time there was no Bāghshāh (royal garden) here. During the reign of Shah 'Abbās a decree was issued to build a structure near Sabza Maidan. They excavated round about the building and flooded it with the water brought from the Bābol river. It was named Dazzakchāl. Before it was flooded, another structure was laid out within

26 xātun '(the) 'lady', is recorded in the text as xavātun, which can be a pseudohistorical orthography ( $x^{v} \bar{a}$ tun). The word can also be understood as a proper name of a woman or a brothel. 
Dazzakchāl. Seventeen piles were erected and a building was built on top [of them]. Once the construction was done, the surrounding area was flooded. Every time they wished to go to that building - a boat was always kept on the water - they would launch the boat to go to the building. Now the building is completely wrecked and only the seventeen piles are left.

5. A sugar mill was built near Sabza Maidan some sixty to seventy years ago. All the machinery was imported from Russia. For a while sugar cubes were made (lit. cooked) in Bārforush and put on the market. When its owner died, people looted (lit. took away) all the sugarmaking apparatus. They even took its (i.e. the defunct mill's) materials. Now there still lie around some equipment that was confiscated by the government.

6. Every winter Dazzakchāl's water is the habitat of every kind of wild bird. Everybody used to go shooting prays and take [home] and consume [the birds]. In the year that the king visited Bārforush, he set a reservation policy preventing people from shooting [birds]; whoever fired a rifle would have his gun confiscated. People, scared, did not open gunfire any more. At present the preservation policy is still in force, but bullets are [still] fired occasionally in retired places.

7. At the same time as Bāghshāh was being built, a waterway was built along [a] line of the bazaar and was paved with bricks. Every year when the winter would arrive, water would be driven from the Bābol river and, for exactly two months, water would flow down into the [canal along the] bazaar, [so] the people's cisterns would be cold. In summer [too] the water of those wells would be very cold. At the present time that bazaar's canal is no longer operating, [another canal named] Shahru has been built. Every year they run water into the Shahru and the water flows into all private wells in the winter. In summertime people drink water from those wells; it is very cold.

8. In the vicinity of [the quarter of] Āqru, Bārforush also has a mosallā. Every time it doesn't rain the imam goes there, [and] a large procession follows him. They say their prayers - it rains.

9. Bārforush has a mosque that is historical. It is called Maqbara. [When] they planned to build the mosque there, having built two or three times, it did not face the qebla. They failed [as] they tried to fix it and eventually quit. After three or four days they noticed that its twelve pillars were all erected and its direction was aligned to the precision of a hair. Everyone says that it was the twelve Imams who placed these twelve pillars so that the alignment became right. 
LÉGENDES SUR LE MAZANDÉRİX BT BARFROUGH. (En masanderiani de Barfroech.)

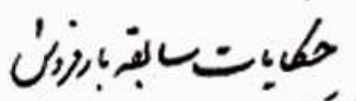

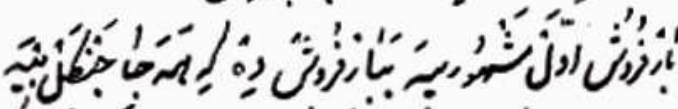

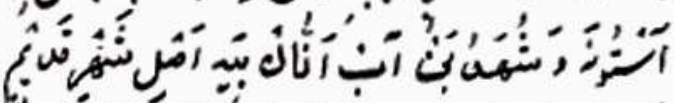

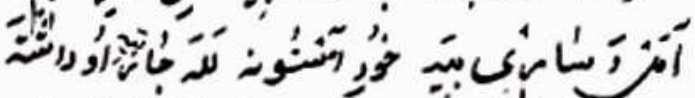

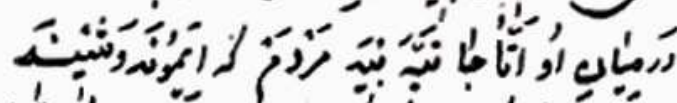

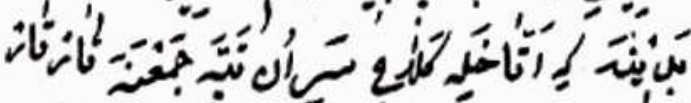

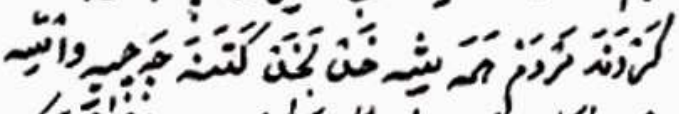

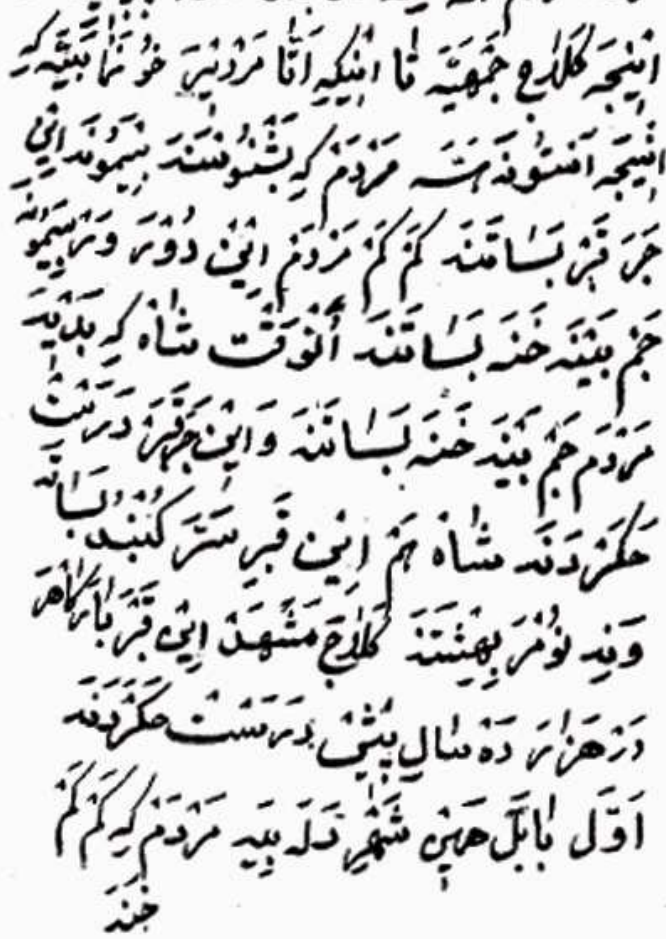


Text II, continued (2)

I. INGUES ET DIALEGTRS DU NORD DE LA PERSE. 253

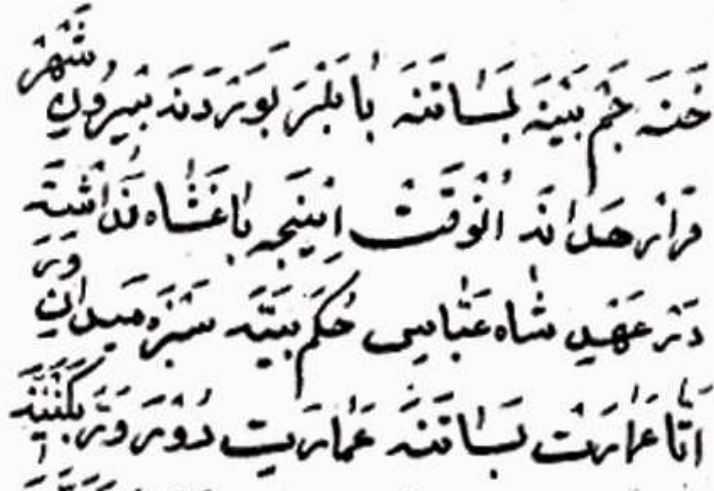

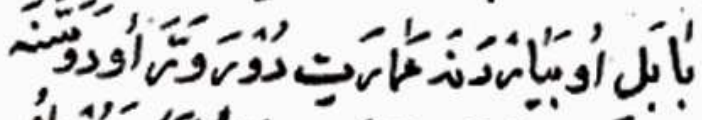

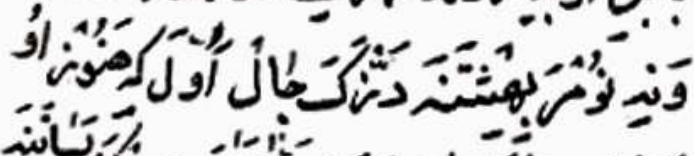

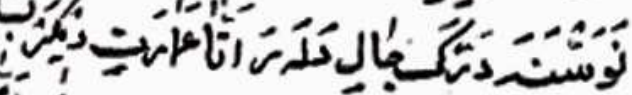

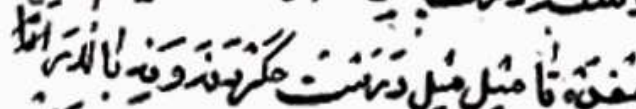
:

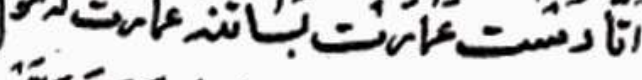

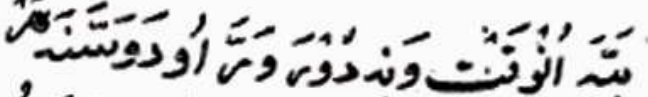

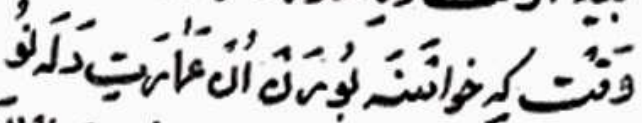

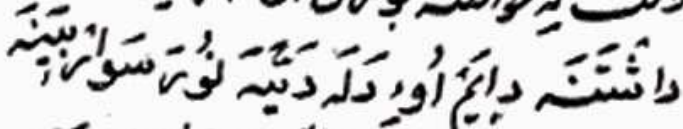

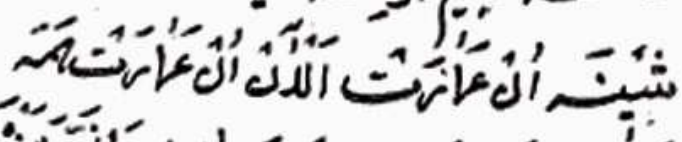

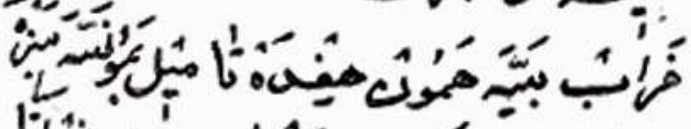

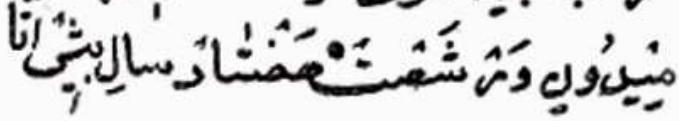


Text II, continued (3)

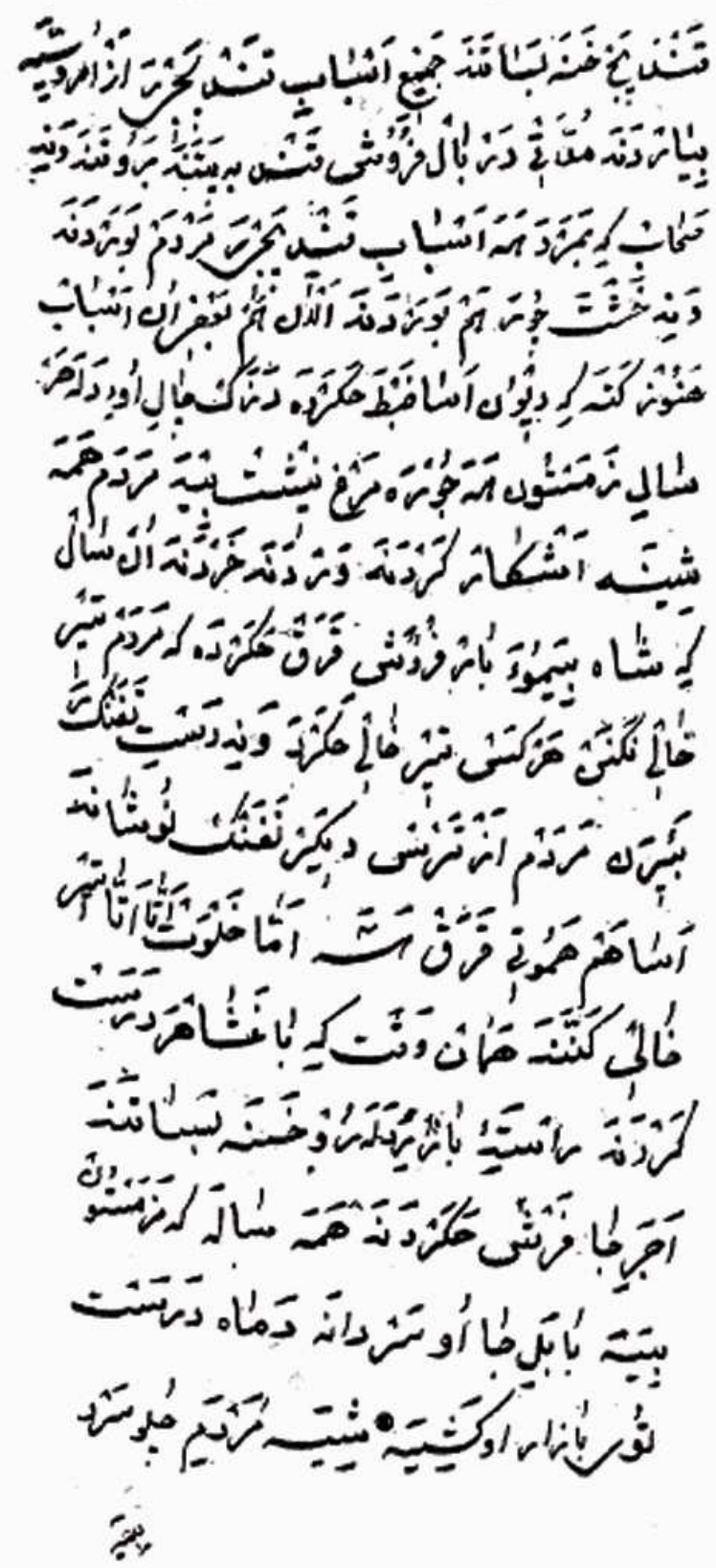


Text II, continued (4)

LANGUES ET DIALECTES DU NORD DE LA PERSE.

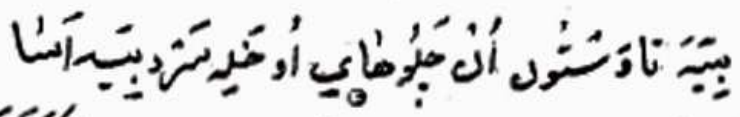

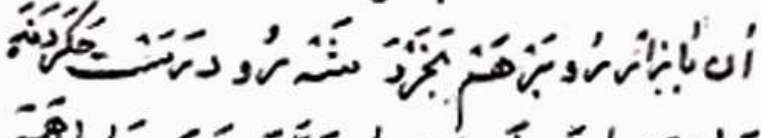

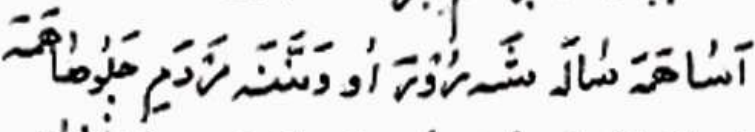

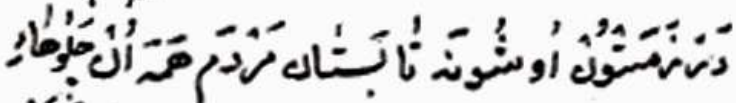
$\because$

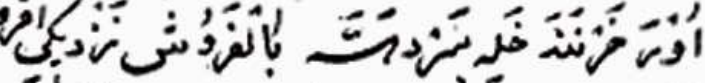

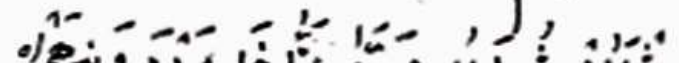

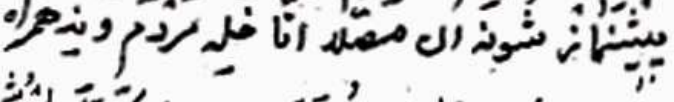

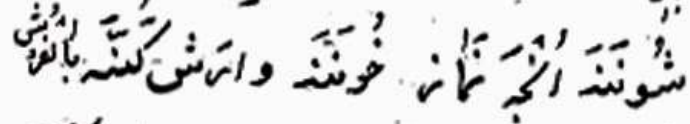

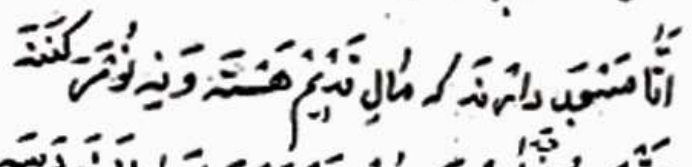

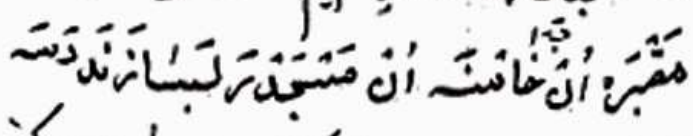

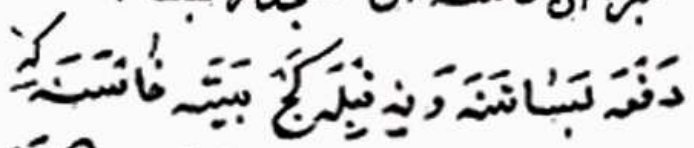

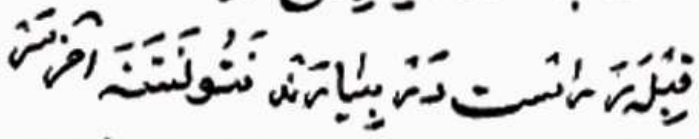

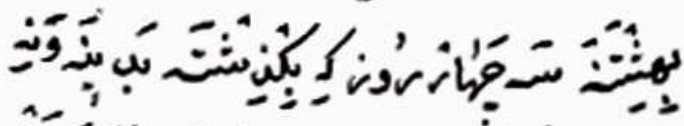

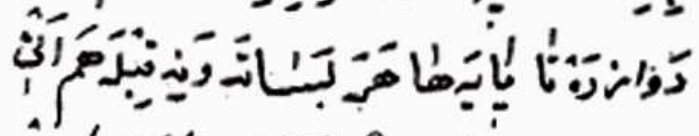

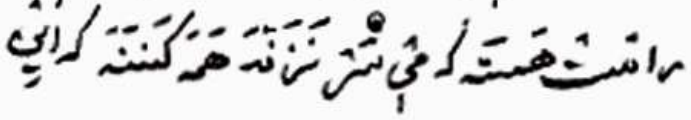


Text II, continued (5)

ÉTUDES LINGUISTIQUES.

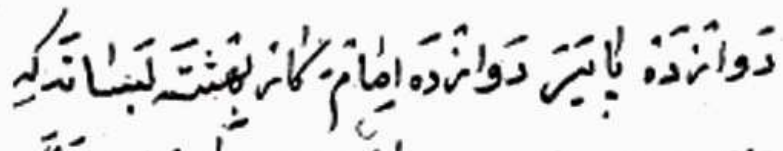

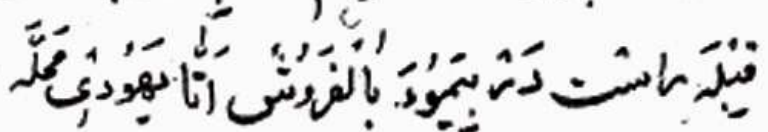

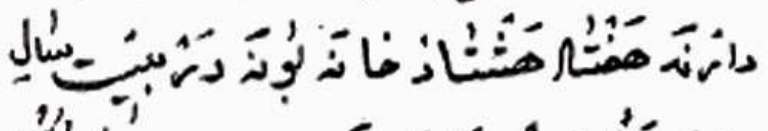

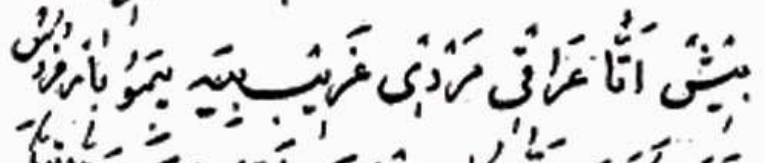

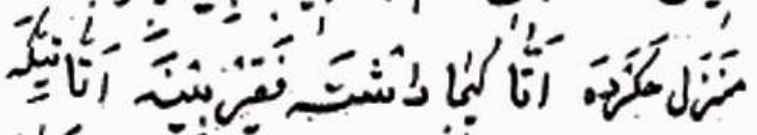
"هانِ

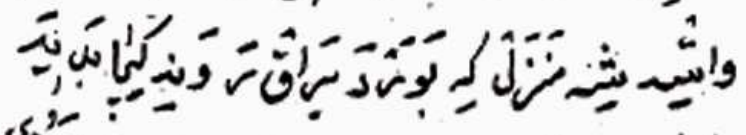

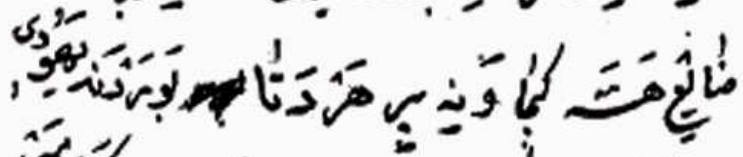

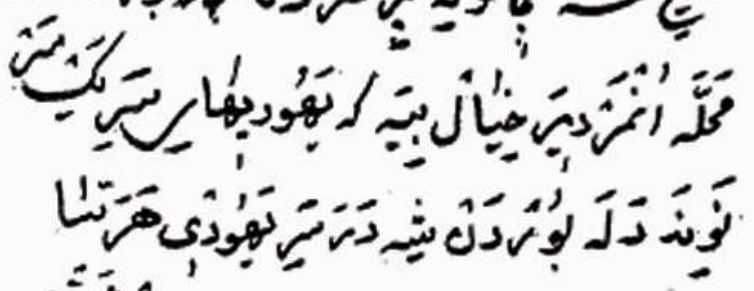

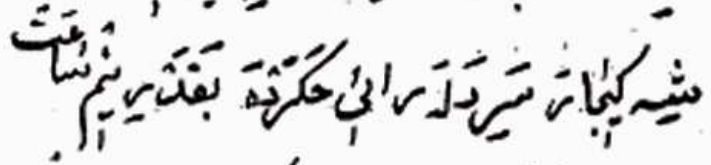

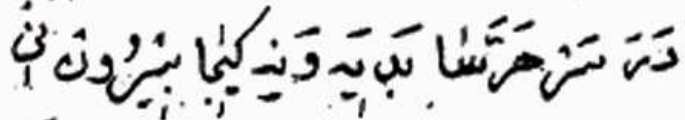

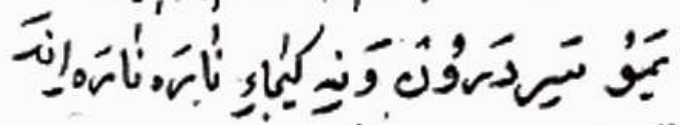

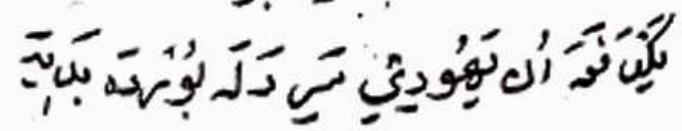


Text II, continued (6)

L.ANGUES ET DIALECTES DU NORD DE LA PRRSE.

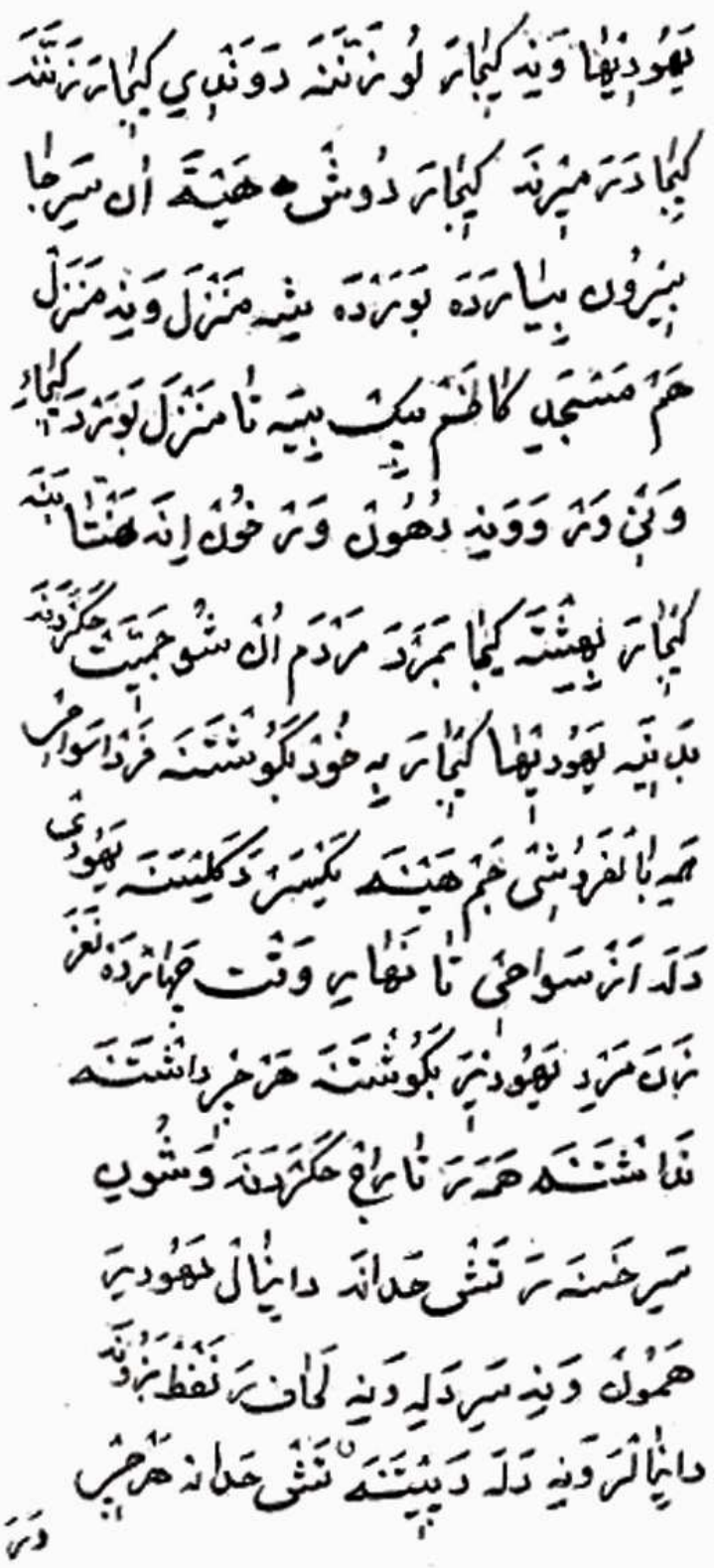


Text II, continued (7)

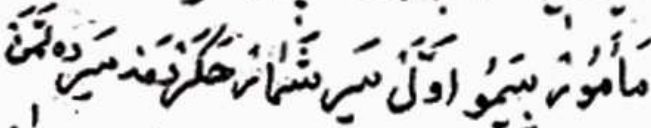
b'

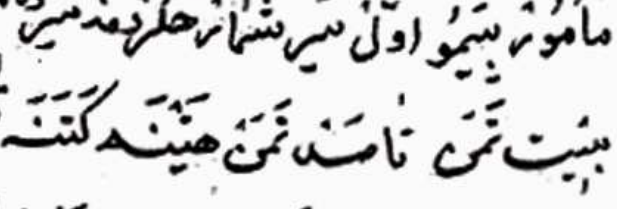

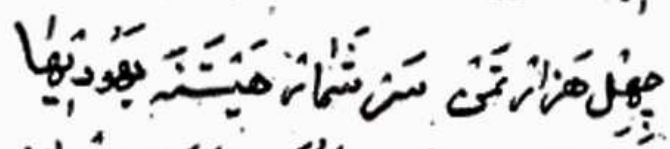

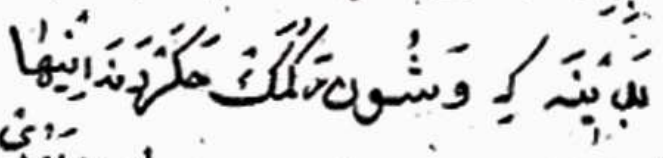

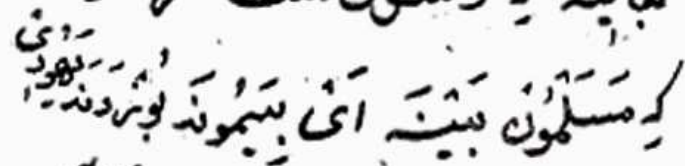

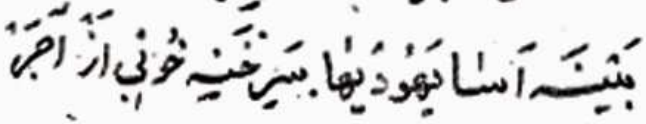

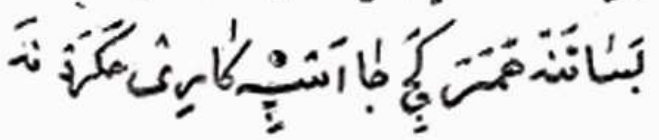


Text II, continued (8)

LANGUes et dilectes dU NORD DE LA PERSE. 259

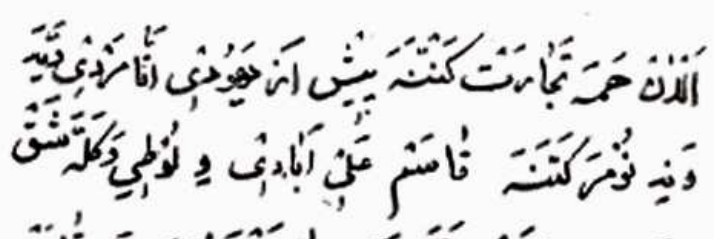

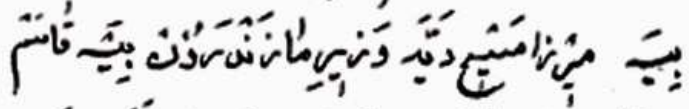

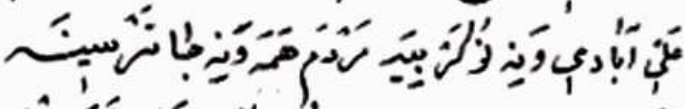

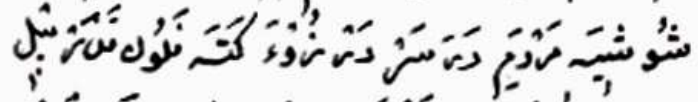

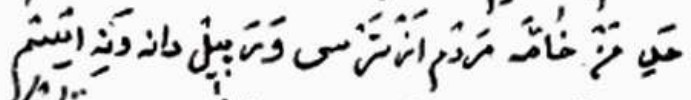

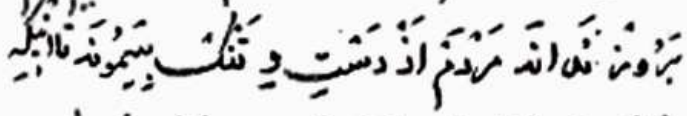

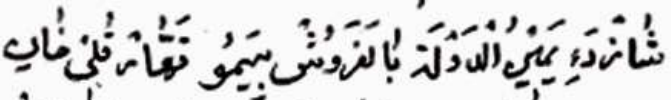

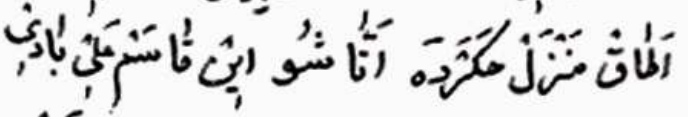

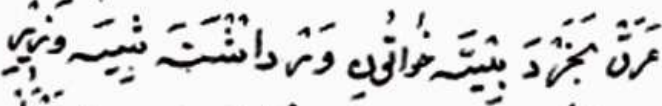

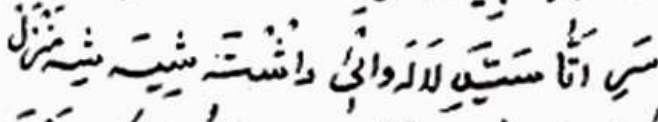

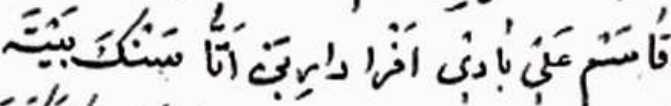

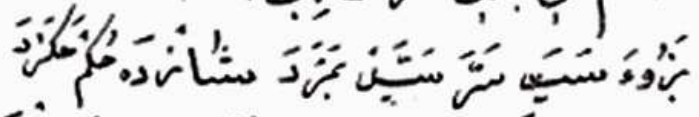

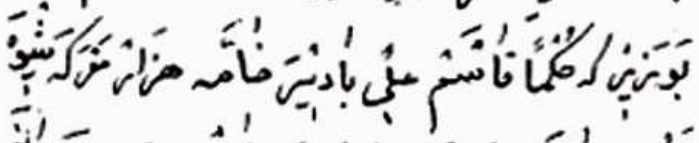

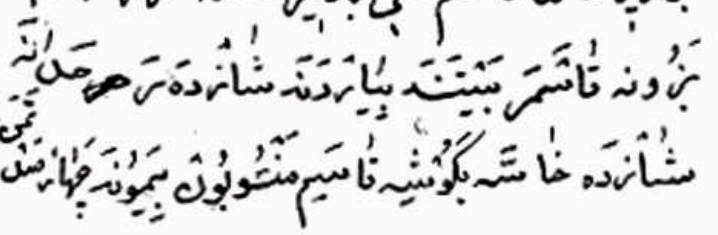


Text II, cont. and end (9).

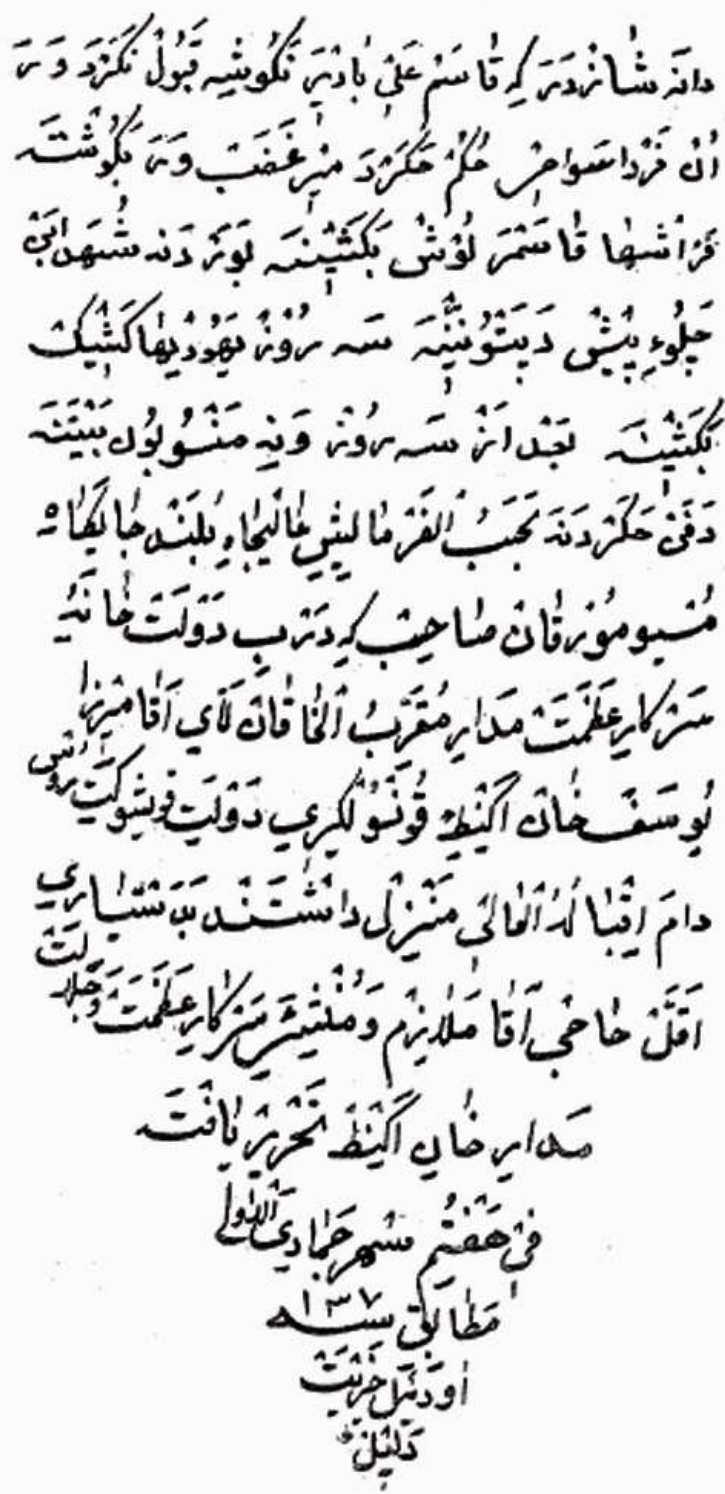


10. Bārforush has a Jewish quarter that comes to seventy to eighty houses. Twenty years ago a man from [Persian] Iraq (i.e. the Iranian plateau) came to live in Bārforush. He had a daughter, and they were poor. He bought a piece of hat's front-lace (?) for his daughter from a Jewish individual. As he took [it] home, his daughter noticed that the lace was defective. Both the girl and her father took [the lace back] to the Jewish quarter. The man assumed that one ought not to go inside a Jew's house uninvited. He stood at the doorway and sent his daughter inside the house.

11. Having waited some half hour at the gateway, he saw that his daughter did not come out; [but] he heard his daughter's groans. Suddenly he went to the Jew's house and saw the Jews were (lit. 'are') kicking and beating his daughter who was tied up, and the girl was about to die. He put the girl on his shoulder, took [her] out of that house and carried [her] to his [own] house. His residence was at Kāzembek mosque. While taking [her] home, blood was (lit. 'is') running from the girl's nose and mouth. As soon as he laid her on the floor, the girl died.

12. That night people assembled and noticed that the Jews [had] killed the girl for no good reason. Next morning all Bārforushis gathered round and all of a sudden swarmed into the Jewish quarter. From morning till noon (?) they killed fourteen Jews of both sexes, plundered whatever they possessed, and set to fire their houses. Daniel the Jew [was attacked] inside his house; they put gasoline on his quilt, wrapped Daniel in it, and set it to fire. Whatsoever they would ask him, "Where is your money?" he replied, "It's in my butts." To the end he did not disclose [where it was].

13. The Jews were somewhat frightened; they all ran away and swarmed into people's houses, and fearfully they would say, "We have become Muslims!' They were (lit. 'became') Muslims for seven or eight months. Muslims in return would invite them over. Finally, the Shah sent a verdict [stating] that "whoever has taken the Jew's properties [must] return [them]." Officials came from the court. First, a census was taken; from each they collected ten, twenty, and up to hundred tumans. They say the collection [?] was up to forty thousand tumans.

14. When the Jews realized that they were supported, those who had become Muslims returned to being Jewish. Currently, Jews have built fine brick houses; they are whitewashed all over with plaster. Now they all are doing business. 
15. Before the Jewish [incident], there was a man named Qāsem 'Aliābādi. He was rogue and bullheaded. There was [a certain] Mirzā Masih who was the vizier of Mazandaran; Qāsem 'Aliābādi was his servant. Everybody was afraid of him. At night he would knock on the people's doors, saying: "Give me such amount of money! I want [it]." Out of fear, people would give him money [but] would not report his name. People were fed up with him.

16. Finally, Prince Yamin-al-Dowla came to Bārforush and stayed in Qahhārqoli Khān's residence. One night Qāsem 'Aliābādi, having gotten drunk, was going [from] the lady's [place?] to the vizier's house. A sayyed from Lalevā was on his way home. At Afrādārban, Qāsem took a stone and crashed [it] into the sayyed's head. The sayyed died.

17. The prince commanded the vizier, demanding Qàsem. [Only] after using a thousand tricks was Qāsem captured and handed over to the prince. The prince wanted to kill [him]. Qāsem's relatives came [forward] to offer the prince 400 tumans to stop the execution. The prince refused it, and in the next morning upon his order the executioner killed him. The servants carried Qāsem's corpse on their shoulders and tossed it in front of Shohadā-ban's cistern. The Jews guarded [the dead body]; after three days his relatives buried [it].

\section{HISTORICAL REMARKS}

The major towns of nineteenth-century Mazandaran were Āmol, Bārforush, and Sāri, all located on the East-West highway traversing the province and situated some 20 miles from one another. Sāri was still the provincial seat, though it had lost its ancient magnificence. Āmol, the other old capital, had also experienced a sharp decline in modern times. Bârforush, on the contrary, had emerged in the late seventeenth century and expanded rapidly as a major trade center with Russia. By the early nineteenth century, Bārforush had grown to one of the largest towns in Persia, with a population of some 100,000. In 1831, however, a plague, transmitted from Russia, ravaged the south Caspian littoral and, together with a subsequent outbreak of cholera, cut Bārforush's population to less than a third. Nonetheless, the town recovered gradually, so well indeed that by 1887 (i.e. two years before our narratives were composed) it had regained its pre-plague population and became, once again, the commercial hub of the southeast Caspian. ${ }^{27}$ Its inhabitants were engaged in business and trade, and there was a Russian consul of trade in the town. Much 
of the merchandise was imported from Mashhad-sar (later Bābolsar), the port of Bārforush, at the mouth of the Bābol river.

\section{II.1. Text $I$}

$\S 1$. The most important monuments of Āmol were situated around Sabza Maidan, near Aspekalā, i.e. one of the eight quarters of the town (cf. Rabino 1928, p. 36). A prominent landscape was the shrine complex of Mir(-e) Bozorg, a title for Mir Qavām-al-Din Mar'ashi (r. 760-781/13591379), the founder of a dynasty of the sādatt, who reigned in Mazandaran from 760/1359 to $c a .989 / 1581 .{ }^{28}$ The present structure of the shrine was erected by the Safavid Shah 'Abbās I (r. 995-1038/1587-1629), a matrilineal descendent of Mir-e Bozorg (Sotuda 1987, pp. 91-1 01). The fortification nearby is described by several travelers, including Fraser (Fraser 1826 , part 3, p. 195). It was known for its huge moat (khandaq), constructed in the late fourteenth century (Zahir-al-Din, p. 271).

$\S 2$. The historical bridge spans the Harāz (see Sotuda 1987, pp. 61- 63; illustrated in de Morgan 1894, I, p. 172). The Mashā'is (incorrectly spelled Mašă $i$, with an $\varepsilon$ ) were one of the "ten clans" of Ämol (Rabino 1928, p. 36), whose summer abode was the valley of Mashā in the highland district of Lārijān, south of Āmol (Kazembeyki 2003, p. 16). Gmelin, in 1771, cited the Mashā'i-mahalla as one of Āmol's eight quarters (Gmelin 1770-84, III, p. 11 5). The Hājji Mashā'i cited in the passage could be Āqā 'Ali Ashraf Mashā'i, who, according to Rabino (1928, p. 37), rebuilt in 1225/ 1810 the western part of Āmol's congregational mosque, which had been destroyed in an earthquake (apparently the earthquake of 1809; cf. EnIr. VII, p. 637). Additionally, Rabino (1928, p. 156, n. 56) reports that the twelve-arch bridge was built originally by a former Sheykh al-Eslām of $\bar{A} \mathrm{~mol}$ at the beginning of the eighteenth century, and that it was rebuilt in the early nineteenth century by Mirzā Shafi', the vizier of Fatḥ 'Ali Shāh Qājār.

$\S 3$. The town was originally located on the western bank of the Harāz, as shown in a topographic sketch by de Morgan (1894, I, p. 172). The appearance of underground structures due to flooding and washed-away soil has an old history: as early as 606/1209-10, Ebn Esfandiār (I, pp. 71f.) alludes to the resurfacing of structures and graves apparently due to a deluge. There were also excavations by treasure diggers all around Āmol (E'temād-al-Salțana, I, p. 6). Cf. excavations in 1860 of Gonbad-e Mohammad-e Āmoli, from which numerous burial chambers were discovered (Melgunov 1868b; Rabino 1928, pp. 39f.). "Iraq", or more 
properly 'Erāq-e 'Ajam "Persian Iraq", was a super-province corresponding to the medieval Jebāl and ancient Media Major. The Caspian author of the text appears to have used the word "Iraq" to mean the entire plateau beyond the Alborz range.

$\S \S 4-5$. Pāyin Gonbad appears to be the Gonbad-ben area in the quarter of Pāyin Bāzār (cf. Sotuda 1987, pp. 48ff.). According to Rabino (1928, p. 39), the old structure of the Emām Hasan mosque was believed to have been built under the caliph Hārun al-Rashid, but as Imam Hasan was reported to have been seen praying there, the mosque was named after him. Âmol was flooded repetitively, breaching the levees constructed at various times (Sotuda 1987, IV, p. 63).

$\S 6$. The size of Āmol was drastically reduced after the outbreak of pandemics of 1831-33, causing its population to shrink from $c a$. 35-40,000 before the plague to some 8,000 in the 1880 s (Kazembeyki 2003, pp. 14f.). The text refers to the outskirts of the old town that had been deserted by the late nineteenth century: Salhār (Cf. Sotuda 1987, p. 29; cited as "Chillar" in Abbott ed. 1983, p. 7); Āləšə-rū, which appears to be the "Alisherood" (Abbott ed. 1983, pp. 7,11 ) and Šahr-rud (Sotuda 1987, pp. 29, 61); and Chālapal, which I could not identify in or near Āmol, but there is a Chālapal bridge at Ashraf (Rabino 1928, p. 62, 122; Sotuda 1987, p. 679). Mazandaranis use the word päyin 'below' to signify 'north', as the land slopes down northward towards the Caspian sea.

$\S \S 7-8$. The shrines of Āmol are numerous, mostly in ruins, with vegetation growing abundantly on their typically octagonal domes (see Rabino 1928, pp. 37-40; idem, texts, pp. 12-14; Sotuda 1987, pp. 48ff., 73ff.; for illustrations, see Hutt and Harrow 1978, pl. 100). The shrine of Mir-e Bozorg (see also §1) is illustrated in de Morgan 1894, I, pp. 173-175; Hutt and Harrow 1978, pl. 102.

§9. Āmela/Āmola is spelled in the Arabic form عامله 'maker, builder' for semantic justification. The old historians of the province (Ebn Esfandiār, I, p. 71; idem, English tr., pp. 20 f., 11 5; Zahir-al-Din, p. 20) have mentioned Āmola, the daughter of Ashtād, as the founder of Âmol. See also Rabino 1928, p. 33; Markwart 1931, p. 136.

$\S 10$. Regarding the underground structures, see de Morgan 1894, I, pp. $172 \mathrm{f}$. There is a similar statement about the availability of construction materials: "There is no need to procure construction materials for those who attempt to build houses in Âmol ... old bricks surface in sufficient amount while digging for the foundation" (E'temād-al-Saltana, I, p. 6). A type of excavated brick was locally known as gabri 
"Zoroastrian" (Rabino 1928, p. 40). This term was used also for old monuments of uncertain origin, especially for many of the conical towers in Āmol (Rabino 1928, p. 37; E'temād-al-Salțana, I, p. 6).

§11. The Royal Garden (Bāghshāh) appears to be the one built by Shāh 'Abbās I (Sotuda 1987, p. 64). In 1844, Holmes reports that the structure existed no more (Holmes 1845, p. 162). Shāh 'Abbās I (see $\S 1$ above) annexed the province in 1005/1597 and showed a particular liking for it; he constructed several palaces there.

$\S 12$. The 'footprints of Khidir' was a tower which stood near the Sabza Maidan in a cemetery known as Mosallā' 'the place of public prayer or oratory' (Rabino 1928, p. 39; Sotuda 1987, pp. 39, 70f.). It is likely to be the old Mosallā' of Āmol, as cited by the medieval historians of Mazandaran (Zahir-al-Din, p. 222; Owliā'-Allāh, p. 80).

\section{II.2. Text II}

$\S \S 1-3$. The present town of Bārforush was founded in the early sixteenth century on the site of the old city of Māmtir. Until the late seventeenth century, however, it was still a village called Bārforushi-deh, which then rapidly expanded in the ensuing century (Zaryāb 1992; Sotuda 1987, pp. 175ff.). Āstāna (lit. 'shrine') and Shohadā-ban (lit. 'martyr-place') were two quarters of the town (cf. Darb-e shohadā29 in Rabino 1928, pp. 157f., n. 69), which were built in the place of a former water reservoir (for which, see Șāleh, pp. 100f.). The hill in the midst of the swamp can be compared with the mount Azraq Dun, described by Zahir-al-Din as having been the site of the house of Azraq, from the Kiā Jalālid clan, who ruled Mazandaran for a short period in the mid-fourteenth century (Rabino 1928, p. 46). Kelāj Mashhad ('tomb of the crows'), first cited by Mir Timur (passim), was also a quarter of Bārforush (Melgunov 1868b, p. 132). The structure (illustrated in de Morgan 1894, I, p. 162) has not survived (Sotuda 1987, p. 185). Thus, the statement by the author of the text claiming that the shrine was 1,010 years old (corresponding to the year 297/909-10) is not supported by the historical documents available to me.

$\S 4$. Bāghshāh stood on an island in the middle of a lake known as Dazzakchāl or Bahr-e Eram. The latter was linked to the Bābol river in the South-East of the town. As was the Bāghshāh of Āmol (see above, I. §11), the royal garden of Bārforush was built by Shah 'Abbās I. By the midnineteenth century, however, only a few stone pillars of the Safavid man-

29 We may infer by comparing Darb-e shohadā 'matyrs' gate' with Shohadā-ban that the latter may have originally been Shohadā-bar, where bar 'door', the authentic NW Iranian word, has been replaced in Mazandarani by Persian dar 'door'. 
sion had survived (Holmes 1845, p. 171). The structure cited in the text (illustrated in de Morgan 1894, I, p. 171) belonged to the earlier Qajar period and was used as an inn by the royal family (Stuart 1854, p. 274; Holmes 1845, pp. 171 f.; Mirzā Ebrāhim, pp. 11 9f.; Nāṣer-al-Din Shāh, pp. 227f.; Rabino 1928, pp. 11 9-121). In 1930, the encircling lake was drained and filled, and it eventually became a residential quarter of Bābol (Sotuda 1987, p. 196).

$\S 5$. The sugar refinery was one of several industrial projects sponsored by the Persian government in the Caspian provinces during the nineteenth century. The plant was established in the early $1850 \mathrm{~s}^{30}$ to process raw sugar from sugarcane, a major staple crop of the province. Its machinery was imported from Saint Petersburg. As the plant failed to be profitable, it was leased to local merchants, but was eventually shut down some time between 1864 and 1874 (Kazembeyki 2003, pp. 78-80; cf. Mahjuri, IV, p. 208).

§6. The lake Dazzakchāl (see above, §4) was a place for fishing and shooting birds (Bābol, p. 164). Nāṣer-al-Din Shāh visited Bārforush in 1864 and 1875 (Nāṣer-al-Din Shāh, pp. 227ff.).

$\S 7$. The water of Bārforush came from the Bābol river through a canal which branched out into cisterns located under residential houses. During wintertime, the water would be flown through this canal until it filled up the cisterns. The stored water would be consumed throughout the year (Mohammad-Taqi Khān Kalim, apud Bābol, p. 175). The canal Shah$\mathrm{ru}(\mathrm{d})^{31}$ (lit. 'royal/great canal') branched off from the left bank of the Harāz (Sotuda 1987, p. 29).

§8. Āqrū or Āqārud was an eastern tributary of the Bābol river as well as a large quarter of Bārforush (Melgunov 1868b, p. 132; Rabino 1928, p. 157 , n. 69; Kazembeyki 2003, p. 20). A moșallā is a public praying field where, for the festival ('id or 'eid) prayers and prayers for rain, the whole population of the town may gather for communal worship (Concise Encyclopaedia of Islam, ed. C. Classe, London, 1989, p. 289).

$\S 9$. The Maqbara ('mausoleum') mosque could be the recently constructed mosque/mausoleum of Sa'id-al-'olamā (Sotuda 1987, p. 206; cf. Șāleh, p. 241), the renowned local clergy who cooperated with the authorities in suppressing the Babi uprising of the mid-nineteenth century; or else, it might be the mausoleum beside the mosque of Kāzembek (Sotuda 1987, pp. 227ff.).

30 The decade of 1820 s is inferred from the text.

31 Cf. Text I, note $\S 6$. 
$\S \S 10-14$. The Jewish community thrived in Bārforush as a result of trade expansion. According to the unpublished manuscript of Capitan F. Mackenzie (Report on the Persian Caspian Provinces), in 1859 the town had over 700 Jewish residences, whose chief (kadkhodā) believed that his colony had been founded by descendants of the Jewish colonies established in Mazandaran by Shah 'Abbās I, who settled many Armenians and Jews in the province (apud Rabino 1928, p. 13). ${ }^{32}$ Curzon believed that the Jewish community dominated the commerce of Bārforush (apud Levi 1984 , p. 765). In the early twentieth century, of the 25,000 inhabitants of the town, 750 were Jews (Rabino 1928, p. 45). The Jewish population began to diminish after the Second World War due to immigration to Israel (Bäbol, p. 173). In the mid-1970s there were still two synagogues in Bābol (Sotuda 1987, p. 244).

The pogrom is reported to have occurred in 1287/1870-71 (Bābol, p. 173) ${ }^{33}$ and 1281/1864 (Levi 1984, p. 641). There are two brief accounts of the incident in Jewish sources, which report the number of casualties 18 and 60 -, and name Dāniāl Mokhtār as one of the casualties (Levi 1984, pp. 641, 699-700). They report also that the shah's decree concerning restoration of the Jewish community in Bärforush was influenced by the British and French embassies in Tehran (ibid.). ${ }^{34}$

$\S \S 15-18$. All we know about the antagonist of the story, Qāsem, is his hometown 'Aliābād, renamed Shāhi in the twentieth century, and later Qā'emshahr. Other localities mentioned in the passages are Lālavā, perhaps a local village, and Afrādārban, a quarter of Bārforush (Sotuda 1987, p. 180). In the Qajar period, Mazandaran was a royal governorate often ruled by a prince-governor, who would be accompanied by a vizier (in charge of collecting taxes) and a financial officer (mostowfi) (cf. Kazembeyki 2003, p. 233). Prince Yamin-al-Dowla appears to have been the province's governor. The vizier, Mirzā Masih Mostowfi (see Fig. 1), was also the owner of several boluks of Sāri at Kalijān-rostāq (Mirzā Ebrāhim, p. 100; Nāṣer-al-Din Shāh, p. 146). Qahhārqoli Khān was the ruler of Bārforush (Nāṣer-al-Din Shāh, pp. 226, 233). The involvement of the Jews in safeguarding the dead body of a criminal is not clear; apparently, it is a groundless statement meant to disgrace the Jewish community of the town.

32 In 1859, there were fifty Jewish households, 2 synagogues, and a Jewish school in Bārforush (Mirzā Ebrāhim, p. 11 8). According to a Jewish source, 150 Jewish households lived in Bārforush in 1864 (Levi 1984, p. 641).

33 Corresponds to the date calculated from the text : $1307-20=1287$.

34 I am greateful of my colleague Ms. Haideh Sahim who brought the Jewish sources to my attention. 


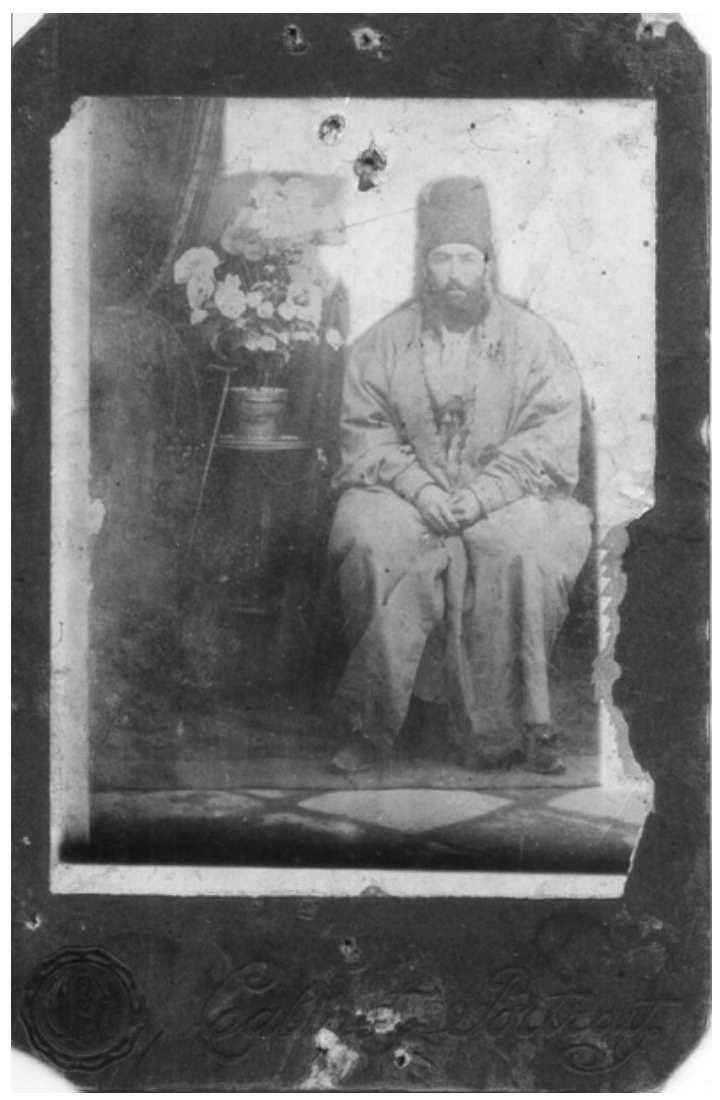

Fig. 1: Mirzā Masih Mostowfi, the vizier of Mazandaran (Text II.15), photographed in 1890s, probably by Sami'-al-Dowla the photographer of the Qajar court, Tehran (C) Courtesy of Mr. Fakhr-al-Din Surtiji)

\section{LINGUISTIC NOTES}

Mazandarani is the mother tongue of three to four million people in the province of Mazandaran. Historically, Mazandarani belongs to the northwestern branch of Iranian, and, together with Gilaki, Talyshi, and the ring of dialects around Semnān forms the so-called Caspian Sprachbund. The dialects of Mazandarani are, by and large, mutually intelligible, at least in Mazandaran proper, but none is considered to be the standard or formal Mazandarani. The dialectal continuum varies in two geographical directions: east-west (valley variation) and north-south (lowland vs. highland). Almost every locale has its own subdialect, and even those of neighboring 
villages may exhibit substantial phonological differences. The lexicon, however, is fairly uniform throughout the province (Borjian 2004a).

Judging by the style and linguistic traits of the texts, one comes to the conclusion that both belong to central-western Mazandaran, but that a different individual composed each narrative. The second text is less Persianized; it contains the authentic Mazandarani traits lacking in the first text, such as the reflexive pronoun $\check{s} e$ (occurring seven times), the ablative marker $j \bar{a}$ (six times), and the postposition vāsse (twice). Nevertheless, certain Mazandarani characteristics, such as the plural marker -un, are absent in both texts (with the exception of mansubun 'relatives' in II.11 9, 124). Furthermore, the texts differ in certain linguistic features, e.g. the preverb $h \bar{a}$ - and the demonstrative pronoun $u n$ in the first text correspond to $h a-$ and $o n$ in the second text, respectively. This demonstrates dialectal differences between the two texts, which are said by de Morgan to have belonged to the town of Bārforush; but one must not forget that Bārforush, in those days, was a trade center and that, hence, its inhabitants were not necessarily indigenous.

As one may expect of a non-written language, the orthography of the texts is far from being accurate. The Mazandarani texts are written in a vocalized Perso-Arabic script, but the diacritic symbols (harakāt) are used neither completely nor consistently. Many words are spelled variously, e.g. <'-v-n> and اون أن <o-n>, corresponding, respectively, to the possible pronunciations $u n$ and $o n$ 'that'; $d o$ and $d a$ 'two'; ajor and ajjor 'brick'; <jm-'> and $<$ ja-m>, representing $j a(:) m$ (with a choice of short or long vowel) 'assembly'; maydun and maydān 'square' (but not the expected Mazandarani midun!); the name of the town Bārforush is spelled variously, including Bālafaruš, a local pronunciation (cf. Holmes 1845, pp. 168f.). There is a pointless handling of the Arabic letter $\tau$ in the Mazandarani words such as حاكردن 'to do'.

No attempt was made to render a consistent spelling in the transcription; instead, individual cases of corrections and reconstructions are explained in the footnotes. Yet my transcription includes two Mazandarani phonemes absent in the manuscripts: (1) $g$, in contradistinction with $k$ (the scribe followed the obsolete Persian orthographic tradition that merges the two phonemes into the letter $ك<\mathrm{k}>$ ); and (2) $\partial$, formally a mid-low, frontcenter vowel, but with a broad allophonic range within and among dialects; its pronunciation varies throughout Mazandaran: while the phoneme is perceived as a kasra $[\mathrm{e}, \varepsilon]$ in eastern Mazandaran, the Babolis find it more relevant to render it a fatha $[\mathrm{a}, \mathfrak{x}]$ when writing their vernacular. Hence, the fatha mark in the text corresponds to two distinct phonemes: $a$ and $ə$, as transcribed in baxriə for the spelling $\left\langle\mathrm{b}^{\mathrm{a}}-\mathrm{x}-\mathrm{r}-\mathrm{y}^{\mathrm{a}}-\mathrm{h}\right\rangle$ 'he bought'. 
The form كن $<\mathrm{k}^{\mathrm{a}}-\mathrm{n}^{\mathrm{a}}-\mathrm{n}^{\mathrm{a}}-\mathrm{h}>$ is transcribed, according to context, as kannənə 'they dig', kənnənə 'they do', or gənənə 'they say'.

The texts are presented, as far as possible, in a normal phonemic transcription that seemed most likely to represent the central-western Mazandarani, in which the accounts are written. As the texts are from more than a century ago, they exhibit certain differences with the dialect as spoken today. Many textual problems - phonological, morphological, and lexical - were tackled by drawing on the other nineteenth-century texts from Mazandaran. Moreover, there are cases where a plain phonemic transcription would disguise or conceal morphological processes. When an essential phoneme is unrealized, a superscript recovers it. Thus, beh štənə indicates a pronunciation be:štəna, but arises from a combination of the morphemes be-(h)ešt-əna 'they let'; biamu' 'he came' represents a pronunciation biamu, where the morpheme -ə, the 3rd person singular ending, is arbitrarily but predictably omitted. The superscript presents, also, the essential phonemes missing in the script, mostly the oblique marker $-e$. Moreover, when $i$ in verb stems is realized as a phoneme, it is retained in the transcription even when $i$ turns to $y$ due to verb stress shift, e.g. baito [bæ'ijit3, 'bæjt3] 'he grabbed,' baitzn [bæj't3n] 'to grab,' bai(r) ['bæ $\mathfrak{j}^{\mathrm{j}} \mathrm{j}^{\mathrm{r}}$ ] 'grab!' This rule generally holds for the verbs 'to be,' 'to be in,' and 'to become,' the pronunciation of which is a matter of choice, e.g. daiz $3^{35}$ ['dæij3, 'dæij3, 'dæjj3] 'it was in'.

\section{GLOSSARY}

This glossary excludes most words which are the same as Persian or have pronunciation only slightly different than in the Persian, namely those differing only in

a for $o, a, e$ : dərast for dorost 'complete', darəšt for dorošt 'thick', zamastun for zemestān 'winter', mərq for morq 'bird', bənā for banā 'construction', etc.;

$u$ or $o$ for $\bar{a}$ before nasals: num for nām 'name', divon for divān 'administration', etc.;

$\bar{u}$ for $o w$ : hüz for howż 'pool', dūr for dowr 'around', nükar for nowkar 'retainer, soldier'.

Verbs are listed under present and/or past stems, separated by a semicolon, followed by the conjugations attested in the texts. Numbers in parentheses refer to text paragraphs. 
Abbreviations

$\begin{array}{llll}\text { aux. } & \text { auxiliary verb } & \text { pron. } & \text { pronoun } \\ \text { comp. } & \text { compound } & \text { sg. } & \text { singular } \\ \text { pers. } & \text { person(al) } & \text { v. } & \text { verb } \\ \text { postp. } & \text { postposition } & \text { v. c. } & \text { causative verb } \\ \text { p. p. } & \text { past participle } & & \end{array}$

āb-annān pond, pool (II. 2).

ašnuss- (v.) listen - b-ašnu ss-ənə they listened (II. 8).

āstunə sacred place, shrine (II. 8); also a toponym (II. 2, 3).

ay then again (II. 101).

bai- $\rightarrow$ bu-.

bait- $\rightarrow(g)$ ir-.

bašnuss- $\rightarrow$ ašnuss-

bəhār-ə-māh spring (I. 31).

-bən (postp.) under, by, beside - used here as a suffix in the toponyms Šohadā-bon (II. 2, 122), Bfrā-dār-e-bən 'under/by the maple tree' (II. $115)$.

bənə ground (II. 80).

bə-on-var across, far side of (I. 9). ${ }^{36}$

bēxud/bexud (adv.) for no good reason (II. 82).

bi- (v.) be - bi-ə was (I. 5, 6, 21- 24, 45, II. 1- 4, 15, 36, 45, 47, 65, 70, 79, 106, 107, 11 3); cf. hass-, dar-.

biamu - $\rightarrow e$ -

biār(d)- $\rightarrow i \bar{a} r-$.

binj rice (I. 10).

bu-; bai-, hai- (v.) become - bu-nə it becomes (II. 64); bai-ə it became (I. 39, II. 7, 18, 25, 29, 57), bai-mi we became (II. 93), bai-nə they became (II. 10, 11, 16, 27, 94, 101, 102), jam hai-ə it came together (II. 7), jam hai-nə they gathered (II. 83). See also na-venə.

bur-, šu-; burd-, ši- (v.) go - šu-nə it goes (II. 50, 53), šu-nənə they go (II. 54), bur-ən that they go (II. 26); burd-ən to go (II. 71), burd-ə he went (II. 75), burd-ənə they went (II. 92, 101), ši-ə he would go (II.

36 Cf. bə-yur 'the other side, across', the antonym of bə-yər lyer 'this side' (Kiā 1947, no. 852; Amirkolāyi 2002). 
46, 108), ši-nə they would go (II. 4, 28, 37), dāštə ši-ə he was going

(II. 11 3, 11 4; see also dār-).

čəči what (II. 6).

čəl-ū water-well, cistern (II. 46, 47, 49, 50, 123).

čū $\operatorname{wood}($ II. 34).

dā- $\rightarrow$ de-

da-, də- (preverb) $\rightarrow$ kalass-, pit-, vann-, dapətunni-.

dai- $\rightarrow$ dar-.

dapatuni- (v.) hurl - dapatuni-na they threw (away) (II. 123). ${ }^{37}$

dār tree - in the toponym $\exists$ frā-dâr-e-bon 'under/by the maple tree' (II. $115)$.

dar-; dai - (v.) be in, exist - dar-ə it is in (I. 42, II. 90); dai-ə there was (I. 6, II. 27, 104, 106); dar-ə mir-nə (aux.) he is dying (II. 77); cf. bi-, hass-.

dār-; dāšt- (v.) have - dār (pres. participle) in gonbod-dār 'having a dome' (I. 49 f.); dār-nə it has (I. 3-6, 14, 15, 17, 23, 29, 36, 37, 45, 49, II. 52, 55, 64), nār-nə it has not (I. 8); dāšt-ə he had (I. 46, II. 3, 66, 11 3), na-dāšt-ə he had not (II. 17), dāšt-ənə they had (II. 27), dāštənə-nadāštənə (II. 85) they had [or] had not; dāštə šiə (aux.) ${ }^{38}$ he was going (II. 114 ).

dar-biamu- $\rightarrow$ dar-e-

dar-biār- $\rightarrow i \bar{a} r-$

dar-e-; dar-iamu- (v. comp.) come out - dar-e-nə it comes out (I. 13, $16,40,41,43,44)$, dar-biamu-ə it came out (II. 63); see also $e$ - .

darəsar gate, doorway (II. 71, 73, 108).

-darun (postp.) inside (II. 74).

dāšt- $\rightarrow$ dār-.

davəndi $\rightarrow$ vand-.

de-; dā- (v.) give - ha-de give! (II. 109), pas ha-de-ən that they give back (II. 96); nə-dā- ${ }^{2}$ he gave not (II. 91), dā-nə they would give (II. 109, 11 9), na-dā-nə they would not give (II. 11 0), sar dā-nə they

37 The stem is obscure, but the form can be scanned as *dapət-und-i-nə, with the causative morpheme $-V n(d)$ - and the past-stem formant $-i-$; cf. Bārforushi <daptounien> daptuni-an, Semnāni <daftounien> 'abaisser' (de Morgan 1904, V, p. 226, no. 581), <dabtanien> 'jeter' (Melgunov 1868a, p. 201), daftuni-no 'they threw (away)' (in Dorn 1865, p. 390, line 11 ), däpartuni-yə 'he shot (an arrow) at' (in Kanz al-asrär, I, p. 25, line 7).

38 Persianized form for Mazandarani daiə šis, where the auxiliary verb is dar-; dai(q.v.) 'be in, exist'. 
would make flow (II. 45), hə-dā-nə they gave (II. 87, 89, 11 8), qərār hə-dā-nə they placed (II. 17).

dələ (adv.) inside (II. 71).

-dələ/-dəle (postp.) inside (I. 29, 32, 42, II. 15, 22, 26, 27, 35, 72, 75, 84, 88-90).

də-sə (lit. 'two-three') a few (II. 56).

di- (v.) see - ba-di-ə he saw (I. 8, II. 10, 68, 73, 75), ba-di-nə they saw (II. 5, 59, 82, 100).

dohun mouth (II. 80).

dūr-ə-var round about, in the vicinity of (I. 16, II. 9, 19, 20, 25).

-e oblique marker (passim); eżāfa marker (passim).

-ē one, each (I. 12, II. 97); cf. - $i$.

ə $\rightarrow$ hass-.

$\partial$ and (II. 13, 14, 34, 84); cf. $o,-\partial-$.

-ə- connective in compound words: bəhār-ə-māh (q.v.), dūr-ə-var (q.v.), dar-ə-sar (q.v.), qand-ə-paj-xənə (q.v.), Čăl-ə-pəl (I. 22f.), Kəlāj-əMašhad (II. 13), Dəzzək-ə-čāl (II. 21, 22), Āq-ə-rū (II. 51); cf. ə, o.

e-; iamu- (v.) come - e-nə comes (I. 50, II. 74, 80), iamu-nə they would come (II. 4), b-iamu-(ə) it came (II. 38, 65, 97, 111 ), n-iamu- ${ }^{2}$ she came not (II. 73), b-iamu-nə they came (II. 8, 9, 101, 110,11 9); see also dar-e-.

əmā (pers. pron.) we (II. 93).

ənə $\rightarrow$ hass-.

əsā now (II. 35, 41, 47, 49, 102).

əškār game, prey (II. 37).

ešmār $\rightarrow$ sarešmār .

ospe white (I. 29); compounded in sspe-kāri whitewashing (II. 103) and in the toponym $\exists$ sspe-kala (I. 1).

ešt- $\rightarrow$ hešt-.

əti this way (variant of inti) (II. 60); a bit (II. 91).

əttā one, few, little (passim); also əttə (II. 52).

əttā-əttā one by one (II. 41).

əttā-xale a lot of (II. 5, 53).

garj plaster (I. 29); but also gač (II. 103).

gat big (I. 4, 15, 24, 36); also gatə (I. 21). 
gə-; gət- (v.) say - gə-nənə they say (I. 2, 4, 5, 21, 25, 28, 38, 48, 50, II. 55, 61); gət-ə he said (II. 90, 108), gət-ənə they said (II. 6, 90, 92, 98, $105)$.

$\mathbf{g}^{2}$ zešt - (v.) pass, elapse - be-gzešt-ə it went by (II. 59).

(g)ir-; (g)it- (v.) get - gir-nənə they take (I. 12), ba-ir-ən that they get (I. 19, II. 40); git- ${ }^{2}$ 'ə they would get (II. 94), ba-it-ə he took (II. 11 5), ba-it-ənə they took (II. 11 8, 124), ha-it-ə he took (II. 77), ha-it-ənə they took (II. 98, 99).

gonbod dome.

ha-, hā-, hə- (preverb) $\rightarrow$ bu-, de-, (g)ir-, kən-, harəssā-.

ham ə-jur(ə) every kind of (I. 46, II. 36).

hamu-ti likewise (II. 41).

hantā as soon as (II. 80).

hass-, $\emptyset$ - (v.) be - is (passim; but also hast-ə (II. 55, 61), -ə is (I. [1], 26, 33, 34, II. 35, 60), ${ }^{39}$-ənə they are (II. 5); cf. bi-, dar-.

hərəssā- (v.) stand - hərəssāa ${ }^{-}-$he stood (II. 71, 73).

hešt- (v.) put - be-hěst-ə he placed (II. 62, 81), be-hešt-ənə they put (I. 39 , II. 13, 21, 59).

-i a(n), one (I. 5, II. 32, 39, 102); cf. -è.

iār-; iārd- (v.) bring - b-iārd-ə he brought (II. 78), b-iārd-ənə they

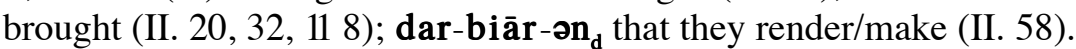

in-jə here (II. 7, 8, 9, 11, 17).

ir-, it- $\rightarrow$ gir-.

-jā (postp.) from (II. 45, 67, 77, 103, 107), with (II. 44).

kan-; kanni-40 (v.) dig - kan-nə he digs (I. 19, 20) kan-nənə they dig (I. 11, 13, 16, 39, 44); ba-kanni-nə they dug (II. 19).

kaši-/kəši- (v.) pull, drag (or aux.) - kaši-ə it would pull (II. 46) bakəši-nə they dragged (II. 122, 124).

kat- (v.) fall - kat (p. p.) fallen (in kát ə it lies, there is) (I. 26, II. 35).

kəjə where (I. 39, II. 90).

-kəlā (toponymic suffix) place - in Aspe-kalā (I. 1).

kəlāj crow (II. 5, 7, 13).

kəless- (v.) pour - da-kəless-ənə they swarmed (II. 83, 92).

39 In all cases the copula -ə appears after a past participle: kat ə (I. 26, II. 35), banəvešt ə (I. 33, 34), bəsāt ə (II. 60).

40 The secondary past stem formant $-i$ - is added to the old past stem kann- $(<$ kand-) to avoid confusion with the present stem when the endings are employed. 
kən-; kərd- (v.) do (mostly used as an auxiliary verb, e.g. binj kənnənə 'they cultivate rice' I. 10) - kən-nə does (I. 43, II. 54), kən-nənə they do (I. 10, II. 42, 104), na-kən-ən that they do not (II. 39); na-kərd-ə it would/did not (II. 52, 120), kərd-ənə they would do (I. 25, 31, II. 6, 37, 43), hā-kərd-ə he did (I. 3, 7, 9, 38, 47), ha-kərd-ə he did (II. 35, 38, 39, 66, 72, 95, 11 2, 11 6, 121), hā-kərd-ənə they did (I. 29, 31, 35), hakərd-ənə they did (II. 12, 14, 23, 44, 48, 81, 86, 91, 97, 100, 103, 125).

kəng anus (II. 90).

kərd- $\rightarrow$ ken-.

kijā girl, daughter (I. 38, II. 66, 68, 69, 72-74, 76, 77, 79, 81, 82).

kuš-; kušt- (v.) kill - ba-kuš-e that he kills (II. 11 9), na-kuš-e that he kills not (II. 120); ba-kušt-ə he killed (II. 121), ba-kušt-ənə they killed (II. 82, 85).

lal ə-jār reed-bed, marsh (II. 3).

lu kick (II. 76).

luš corpse (II. 122).

mardi man (II. 7, 65, 70, 104).

me (pers. pron.) my (II. 90).

mən (pers. pron.) I (II. 109).

mərd- $\rightarrow$ mir-.

mi hair (II. 61).

mir-; mərd- (v.) die - darə mir-nə he is dying (II. 77), ba-mərd-ə (s)he died (II. 33, 81, 11 6).

munəss- (v.) stay - ba-munəss-ə it stayed (II. 29).

nārə shout (II. 74).

na-venə (v. modal) should not (II. 71) (precedes the infinitive burdən). Cf. $b u-$.

nəvešt- (v.) write - ba-nəvéšt (p. p.) written (I. 33, 34).

ništ seat, abode (II. 36).

nū boat (II. 26, 27).

núšā-nə (v.) they would/did not open (a gunfire) (II. 40). ${ }^{41}$

o and (I. 3, 4, 11, II. 2, 80, 95, 105); cf. $ə,-\partial-$.

on that (II. 5, 26, 28, 34, 37, 47, 49, 50, 53, 56, 70, 75, 77, 81, 121); also un (I. 12).

41 The past stem can be bušă- or vešă- (Cf. Chodzko 1842, p. 577, no. 15; Kiā 1947, nos. 366, 794). 
on-jə there (II. 54, 56); also un-jə (I. 24).

on-vaqt then (I. 9, II. 10, 17, 25); also un-vaqt (I. 7).

paj-; pət- (v.) cook - -paj- (pres. stem) in the compounds qand-ə-pajxənə, qand-paji (qq.v.); ba-pət-ənə they cooked (II. 32).

pəllə arched span of a bridge (I. 6, 7).

per father (II. 69).

pət- $\rightarrow$ paj-.

pil money (II. 90, 95, 108, 109).

-piš (postp.) near, by, beside, in front of (II. 123).

pit- (v.) wrap - da-pit-ənə they wrapped (II. 89).

qand-ə-paj-xənə sugar factory (II. 31).

qand-paji sugar refining (II. 31, 33).

rāi traveler (II. 72).

(-r)ə (postp.) direct object marker (passim); indirect object marker: Šäzdə-ro hadānə 'they gave [him] to the Prince' (II. 11 8), bazuə Sayyad-e sar-ra 'he struck [the stone] on the man's head' (II. $113 \mathrm{f}$.); note also on mardi-rə xiāl biə ke ... 'that man thought that ...' (II. 70).

rū stream, creek, canal (II. 48, 49); also in the hydronyms $\bar{A} l \partial s ̌$-rū (I. 22), Šah-rū (II. 48, 49), and $\bar{A} q \partial-r \bar{u}$ (II. 51); see also ruxənə.

rut- (v.) sell - ba-rut-ənə they sold (II. 32).

ruxənə canal (II. 43); see also rū.

-sar (postp.) above, over (II. 12).

sar-ešmār census (II. 97, 99).

sar-ruzə dome (I. 28) (ruzə< Ar.-Pers. rawża?).

sāz-; sāt- (v.) make - bə-sāz-ən ${ }_{d}$ that they build (II. 56); bə-sāt-ə he built (II. 12, 62), bə-sāt-ənə they built (II. 9-11, 16, 19, 22, 24, 31, 43, 57, 103), bə-sāt (p. p.) built (II. 60).

še (pers. and reflexive pron.) self, his (II. 6, 67, 68, 71, 72, 78, 11 4); cf. $x \partial d$.

səre house (II. 70, 72, 74, 75, 77, 88, 11 4).

səre-xənə house (II. 87, 92, 102); see also xənə.

səvāhi morning (II. 82, 84, 121).

ši-, šu- $\rightarrow$ bur-.

šū night (I. 50 II. 81, 108, 11 2).

tarsi-/tərsi- (v.) be afraid - társi-nə they would be scared of (II. 107), bá-tərsi-nə they were afraid (II. 91). 
taš fire (II. 87, 89).

tāvəstun summer (II. 47).

te (pers. pron.) your (sg.) (II. 90).

tunass- (v.) be able to - na-tunəs s-ənə they would not be able to (II. $58)$.

$\overline{\mathbf{u}}$ water (I. 7, 9-11, 18, 20, 31, 32, II. 3, 4, 20, 21, 25, 27, 35, 45, 46, 4851).

un- $\rightarrow$ on; on-ja; on-vaqt.

vann-; vəndi-, vəss- (v.) bind, tie; flood (when preceded by $\bar{u}$ 'water')

- $\bar{u} \operatorname{van}^{\mathrm{n}}$-nənə they flood (the land) (I. 11, II. 49); da-vəndi (p. p.) wrapped (II. 76), $\bar{u}$ da-vəs s-ənə they flooded (II. 20, 25), $\bar{u}$ na-vəs sənə they did not flood (II. 22).

-var (postp.) by, toward, at (I. 1, 3, 4, 30, II. 18, 30, 80, 11 3).

vard-/vərd- (v.) carry (also aux.) - vard-ənə they would take (II. 37), ba-vərd-ə it took (I. 7, 10, 18, 20, II. 68, 78, 79), na-vərd-ə it took not (I. 9, 18), ba-vərd-ənə they took (II. 16, 33, 34, 69, 96, 122).

vārəš rain (II. 52, 54).

-vāsse (postp.) for (II. 6, 68); cf. -var.

ve (pers. pron.) he, she, it (I. 45, II. 105, 11 0); vərə (ve/va + ra) (I. 11, 25, 31, 48, II. 89, 109, 120, 121); cf. vəne.

venə $\rightarrow$ navenə.

vóne (pers. pron.) his, him, its (oblique case of ve) (I. 28, 31, 33, 38, II.

$13,21,23,25,32,34,39,53,55,57,59,60,68,69,73,74,76,78,80$,

$88,89,105,107,109,124)$.

vəni nose (II. 80).

-vər (postp.) for; in-e var therefore (I. 25); cf. -vāsse.

vəs s- $\rightarrow$ vann-.

vəšun (pers. pron.) they (II. 94, 100).

vəšúne (pers. pron) their (II. 86).

xā-; xāss- (v.) want - xā-mmə I want (II. 109, 11 7); xāss-ə he wanted (II. 11 9), xāss-ənə they wanted (II. 26, 56, 57).

xále many (I. 4, 19, 24, 31 II. 47, 51); see also sttā-xale.

xarin-; xəri- (v.) buy - xarin-nənə they buy (I. 11 ); ba-x əri-ə he bought (II. 67).

xəd self (reflexive pron.) (I. 3, II. 6); but also xud (II. 3); cf. še.

xənə house (II. 10, 11, 16); see also sərexənə, qandəpajxənə, ruxənə. 
xər-; xərd- (v.) eat, drink - xər-nənə they drink (I. 32, II. 51); xərdənə they would eat (II. 37), bar-ham ba-xərd-ə (aux.) it is destroyed (I. 35f., II. 48), ar $q$ baxərdə biə (past perfect tense) he had drunk vodka, or arəq-baxərdá biə (p. p., adjective) he was drunk (II. 113 ).

xud $\rightarrow$ xad.

xun- (v.) read - nəmāz xun-nənə they pray (I. 51, II. 54).

$\mathbf{x} \overline{\mathbf{u}}$-nəmā dream (II. 7).

zan-/zən-; zu- (v.) hit (or aux.) - zan-nənə they are hitting (II. 76), nazən-nə it does not hit (II. 61); zu-ə he would knock (II. 108), ba-zu-ə he struck (II. 11 6), ba-zu-nə they hit (II. 88, 11 8).

\author{
Habib BORJIAN \\ Caucasian Centre for Iranian Studies \\ Khorenatsi Street, 26 \\ 375010 Yerevan \\ Armenia \\ $<$ <b146@columbia.edu>
}

\title{
BIBLIOGRAPHY
}

Abbott ed. 1983: Abbott, K.E., Cities \& Trade: Consul Abbott on the Economy and Society of Iran 1847-1866, ed. Abbas Amanat, London, 1983.

Amirkolāyi 2002: Amirkolāyi, Ebrāhim, "Pol-e davāzdah-čašma-ye Āmol," in Z. Dargāhi, ed., Majmu'a-ye maqālāt-e farhang-e Māzandarān, Tehran, 1381sh./2002, pp. 53-59.

Bābol: $\quad$ Bābol šahr-e bahār-nārenj, Tehran, 1379sh./2000.

Berezin 1853: Berezin, Il'ya Nikolaevich (E. Berésine), Recherche sur les dialects persans, 3 parts, Kazan, 1853.

Borjian 2004a: Borjian, Habib, "Mazandaran: Language and People: The State of Research," Iran and the Caucasus 8/2 (2004), pp. 289-328.

2004b: id., 'Personal and Reflexive Pronouns in Mazandarani," Orientalia 2 (2004), pp. 7-13.

2005a: id., "The oldest known prose text in modern Tabari: A translation from Tüfän al-bokā," Studies on Persianate Societies 3 (2005), pp. 172-189.

2005b: id., "Šenāsa-ye fe'l dar māzandarāni-e šarqi (Personal endings in Eastern Mazandarani verbs)," Guyeš-šenāsi/ Dialectology 1/3 (2005), pp. 13-19.

2006a: id., "The Oldest Known Texts in New Tabari: Collection of Aleksander Chodźko," Archiv Orientální 74/3 (2006), pp. 153-171. 
2006b: id., "A Mazandarani Account of the Babi Incident at Shaikh Tabarsi," Iranian Studies 39/3 (2006), pp. 381- 400.

2006c: id., "Tabari language materials from Il'ya Berezin's Recherches sur les dialectes persans," Iran and the Caucasus 10/2 (2006), pp. 243-258.

2008: id., "Nesāb-e Tabari Revisited: Dialect Materials from the NineteenthCentury Mazanderani Dictionary," in Kia Memorial Volume, A. Bahrami (ed.), Tehran, 2008, pp. 44-75.

Borjian, Habib, and Maryam Borjian (Mohammadi Kordkheili), s.v. "Amir Pāzvāri," Encyclopaedia Iranica, Ehsan Yarshater (gen.ed.), New York, 1982-, Supplement (available online at www.Iranica.com).

Calmard 1988: Calmard, Jean, "Mar'ashis," in Encyclopedia of Islam (new edition), vol. VI: Paris-Leiden, 1988, s.v.

Chodźko 1864: Chodźko, Aleksander Borejko, Specimens of the popular poetry of Persia, London, 1842; 2nd ed. London, 1864.

Dorn 1865: Dorn, Boris Andreevich, Morgenländische handschriften der kaiserlichen öffentlichen bibliothek zu St. Petersburg. Nachträge zu dem Verzeichniss der im Jahre 1861 erworbenen Chanykov'schen Sammlung, St. Petersburg, 1865.

Ebn Esfandiār, Tārikh-e Tabarestān, ed. 'Abbās Eqbāl, Tehran, 1320sh./1941; English translation by Edward G. Browne, as An abridged translation of the history of Tabaristān, Leiden, 1905.

EnIr.: Encyclopaedia Iranica, Ehsan Yarshater (gen.ed.), Encyclopaedia Iranica Foundation - Columbia University, New York, vol. I-..., 1982- .

E'temād-al-Salțana, Mohammad-Ḥasan Khān, Mer'āt al-boldān, Tehran, 1297/1880.

Fraser 1826: Fraser, J. B., Travels and Andentures in the Persian Provinces on the Southern Banks of the Caspian Sea, London, 1826.

Gmelin 1770-84: Gmelin, Samuel Gottlieb, Reise durch Russland zur Untersuchung der drei Naturreiche, 4 vols., St. Petersburg, 1770-1784.

Hanway 1753: Hanway, Jonas, An historical account of the British trade over the Caspian Sea, with a journal of travels and the revolutions of Persia, 4 vols. London, 1753 (reprinted in 2 vols., London, 1962).

Holmes 1845: Holmes, William Richard, Sketches on the Shores of the Caspian, Descriptive and Pictorial, London, 1845.

Hutt and Harrow 1978: Hutt, A., and L. Harrow, Iran, volume II, London, 1978.

Kanz al-asrār, ed. B. A. Dorn, Beiträge zur Kenntnis der iranischen Sprachen, St. Petersburg, 1860-1866.

Kazembeyki 2003: Kazembeyki, Mohammad Ali, Society, Politics and Economics in Māzandarān, Iran, 1848-1914, London, 2003.

Kiā 1947: Kiā, Șādeq, Vãžanāma-ye țabari, Tehran, 1326sh./1947.

Levi 1984: Levi, Habib, Tārikh-e Yahud-e Irān, volume III, Tehran, 1339sh./1960; repr. California, 1984.

Mahjuri 1963-66: Mahjuri, Esmā‘il, Tārikh-e Māzandarān, 2 vols., Tehran?, 13421345sh./1963-1966.

Markwart 1931: Markwart, J., A Catalogue of the Provincial Capitals of Erānshahr, ed. G. Messina, Rome, 1931. 
Melgunov 1868a: Melgunov (Melgounof), G. V., "Essai sur les dialectes du Masenderan et du Guilan, d'après la prononciation locale", Zeitschrift der Deutschen Morgenlandischen Geselaschaft 22 (1868), pp. 195-224.

1868b, id., Das Südliche Ufer des Kaspischen Meeres, Leipzig, 1868.

Mirzā Ebrāhim, Safarnāma-ye Astarābād o Māzandarān o Gilān o..., ed. Mas‘ud Golzāri, Bonyād-e Farhang-e Irān, 238, Tehran, 1977.

Mir Timur Mar'ashi, Tārikh-e khānadāne Mar'aši-ye Māzandarān, ed. Manuchehr Sotuda, Tehran, 1364sh./1985.

Morgan 1894-1904: Morgan, Jacques de, Mission scientifique en Perse, 5 vols., Paris, 1894-1904.

Nāṣer-al-Din Shāh Qājār, Ruznāma-ye safar-e Māzandarān, Tehran, 1294/1877; repr. Tehran, 1356sh./1977.

Owliā'-Allāh Āmoli, Tārikh-e Ruyān, ed. Manuchehr Sotuda, Tehran, 1347sh./1969.

Rabino 1928: Rabino, H. L., Mazandaran and Astarabad, London, 1928.

Sotuda 1987: Sotuda, Manuchehr, Az Āstārā tā Estārbād, volume IV, Tehran, 1366sh./1987.

Stodart ed. 1960: Stodart, R., The Journal of Robert Stodart, ed. Sir E. Denison Ross, London, 1935; Persian translation by Ahmad Tavakkoli in Farhang-e Irānzamin 7 (1960), pp. 161- 220

Stuart 1854: Stuart, Charles, Journal of a Residence in Northern Persia, and the adjacent Provinces of Persia, London, 1854.

Ṣāleh Ṭabari 1999: Șāleh Ṭabari, Șamad, Bābol šahr-e talā-ye sabz, Tehran, 1378sh./1999.

Zahir-al-Din Mar'ashi, Tārikh-e Tabarestān o Ruyān o Māzandarān, ed. Manuchehr Sotuda, Tehran, 1349sh./1970.

Zaryāb 1992: Zaryāb, "Abbās, "Bābol," in Dānešnāma-ye Jahān-e Eslām, ed. S.-M. Mirsalim, vol. I, Tehran, 1371sh./1992, p. 86. 